\title{
Akademik Taylorizm, Performans Yönetimi ve Akademik Üretimde Niceliğin Önemi: Akademisyenler Üzerine Niteliksel Bir Çalışma*
}

\author{
Dr. Öğr. Üyesi Selin Atalay \\ İzmir Bakırçay Üniversitesi, Fen Edebiyat Fakültesi \\ Sosyoloji Bölümü \\ la_celina@hotmail.com
}

Öz

Bu çalışmanın amacı, Türkiye'de yükseköğretim alanında ortaya çıkan performans yönetimi anlayışının bir yansıması olan akademik üretim sürecini değerlendirmektir. Bu çerçevede çalışmada, 'Emek Süreci Kuramı' kuramsal bakış açısından akademik emek süreci ele alınmış ve temel bir akademik faaliyet olan yayın yapma süreçlerinde 'Akademik Taylorizm'in etkisi değerlendirilmiştir. Akademik emek sürecinde Taylorizm, akademisyenlik mesleğinin zanaat yapısının bozulması ve zanaat bilgisinin yönetimlere aktarılması temelinde ortaya çıkmaktadır. Bu çerçevede, akademik işin standartlaştırılmış, ölçümlenebilir ve böylelikle denetlenebilir hale getirilmiş olduğu görülmektedir. Akademide iş güvencesi sorunlu hale gelirken, akademik emeğin kendisinden beklenen performansı sergileme yönünde hareket eder hale gelmesi söz konusu olmaktadır. 2017 yılında, Türkiye'de yükseköğretim alanında gerçekleşen dönüşümün akademik emek üzerindeki etkisini anlamak üzere bir çalışma gerçekleştirilmiştir. İstanbul ve İzmir illerinde yer alan vakıf ve devlet üniversitelerinde sosyal bilimler alanlarında çalışmakta olan, farklı ünvanlara sahip 28 öğretim üyesi ile derinlemesine görüşme yapılmıştır. Araştırmadan elde edilmiş niteliksel verilerin bu çalışma kapsamında değerlendirilmesi sonucunda, yüksek öğretimde Taylorizm stratejilerin uygulanması ile birlikte akademik işin yoğunlaştırıldığı görülmüştür. Bu yoğun iş yükü çerçevesinde, yayın sürecinde akademik emeğin sözleşme yenileme ya da kariyerinde ilerleme motivasyonu ile, 'stratejik' olarak nitelendirilebilecek yayın yapma yollarını benimseyebilmesi söz konusudur. Kısa sürede yayın yapma ya da 'puan' toplama adına akademisyenler bir stratejik düşünme şekli geliştirmektedirler. Bu çalışma, yayın yapma sürecinin bir akademik faaliyet olarak araç yerine amaç haline gelmekte olduğuna ve niceliğin niteliğe öncelendiği bir anlayışın akademik üretime hakim olmakta olduğuna dair tartışma çerçevesinde akademik Taylorizmin yükselişini ele almaktadır.

Anahtar Kelimeler: Akademik Taylorizm, Emek Süreci Kuram1, performans yönetimi, yayın süreci, yükseköğretimde dönüşüm.

\footnotetext{
* Bu makale, Prof. Dr. Hale Okçay danışmanlığında tamamlanan Yükseköğretim Stratejileri ve Akademisyenlik Mesleğinin Değişimi: Sosyal Bilimler Örneği başlıklı Doktora tezinden üretilmiştir. 


\title{
Academic Taylorism, Performance Management and the Importance of Quantity in Academic Production: A Qualitative Study on Academics**
}

\begin{abstract}
The purpose of this study is to evaluate academic production, which reflects the emerging notion of performance management in Turkey's higher education. In this context, academic labor process is assessed through the theoretical framework of 'Labor Process Theory' and the effects of Academic Taylorism on the publication process, which is a fundamental academic endeavor, are analyzed in this study. Taylorism in academic labor process entails, the deterioration of the craft structure inherent in academic profession and the transfer of craft knowledge to the management. Accordingly, academic work is standardized, made measurable and hence controllable. While job security becomes problematic in academy, it is seen that academic labor acts in such a way as to guarantee the expected performance. In the year 2017, a study is conducted to understand the effects of the transformation of Turkey's higher education on academic labor. In-depth interviews have been conducted with 28 faculty members carrying different titles, working in social sciences departments of public and foundation universities located in the cities of Istanbul and Izmir. The evaluation of the qualitative data obtained from research, here has shown that academic work is intensified through the implementation of Taylorism strategies in higher education. Within the scope of an intense workload academic labor, with the motivation, created through contract renewal and to achieve career advancement, can adopt a more strategic, way of publishing. To demonstrate the expected performance and to publish work and collect performance 'points' in a short period of time, academics develop a strategic way of thinking. This study focuses on the rise of academic Taylorism through the discussion that publishing process is turning into an academic activity, which is an end rather than the means and an understanding which favors quantity over quality is taking over academic production.
\end{abstract}

Keywords: Academic Taylorism, Labor Process Theory, performance management, publication process, transformation of higher education.

** This article is derived from the PhD study titled "Higher Education Strategies and The Changing Academic Profession: Case of Social Sciences" 


\section{GíRiş}

Tüm dünyada yükseköğretim alanında, neoliberal politikalar temelinde bir dönüşümün gerçekleştiği görülmektedir. Bu dönüşüm, var olan yükseköğretim sistemlerinde, bilimsel yönetim anlayışının yükselişi temelinde gerçekleşmektedir. Özel sektör modelinden devralınan verimlilik ilkelerinin, Taylorizmin, yükseköğretime ve böylelikle akademik emek sürecine uygulanması söz konusu olmaktadır. İki temel akademik faaliyet olan ders verme ve araştırma faaliyetleri artan bir şekilde standartlaştırılmakta, ölçümlenebilir kılınmakta ve bu temelde akademik emek, süreklileşen bir performans yönetimine tabi olmaktadır. Bu çalı̧̧ma, Türkiye için de geçerli olacak şekilde, performans yönetiminin temel odağı olan yayın performansı ve bu çerçevede ortaya çıkan nicelleştirme eğilimini, 'stratejik' yayın yapma anlayışını ele almaktadır.

Akademik Taylorizasyon olarak ele alınan, yükseköğretimde gerçekleşen dönüşüm, akademik emek sürecinin herhangi bir başka emek süreci gibi bilimsel yönetim ilkelerine tabi olmasını getirmiştir. Bu temelde, ilk olarak emek süreci ve bilimsel yönetim kavramları tartışılacak, emek ve emek gücü ayrımı üzerinden, emek sürecine uygulanan bir yönetsel strateji olan Taylorizm ele alınacaktır. Bu tartışmayı, akademik emek sürecinde ortaya çıkan yeni stratejiler ve akademisyenlik mesleğinin dönüşümüne ilişkin tartışma izleyecektir. Bu temelde yükseköğretimde neoliberal dönüşüm, dünyada ve Türkiye'de yaşanan değişimler üzerinden değerlendirilecek sonrasında, Türkiye'de akademik Taylorizasyon, bilimsel yönetimin yükselişi, somut gelişmeler üzerinden analiz edilecektir.

Tüm bu gelişmeler temelinde yükseköğretimde bilimsel yönetim anlayışının bir sonucu olarak performans yönetimi ve bu anlayış üzerinden, akademik işin yoğunlaştırılması ele alınacaktır. Bu çerçevede, akademik yayın sürecinde sayısallaştırma, niceliğin nitelik önünde kazandığı önem üzerinde durulacaktır. Bu tartışmaya 2017 yılında gerçekleştirilmiş araştırma sonucu elde edilen niteliksel verilerin analizi dahil edilecektir. Yayın performansı üzerine kurulmuş olan bilimsel yönetim anlayışının olumsuz sonuçları ele alınacak, performans gösterebilirlik adına benimsenen hızlı yayın yapma stratejileri, bu dönüşüm sürecinde böylesi bir akademik üretim alanında ortaya çıkan ve yaşanan gelişmeleri araçsallaştıran yeni mecralar, yayın yapmanın araç yerine amaç haline gelmesi gibi gelişmeler değerlendirilecektir.

\section{EMEK SÜRECI VE BİLIMSEL YÖNETIM ANLAYIŞININ YÜKSELIŞ̧i}

Emek ve emek gücü kavramları temel bir ayrıma işaret etmektedir. 'Emek gücü' emekçinin sahip olduğu realize edilmemiş bir emek potansiyelidir. Emek ise emek gücünün işe koşulması sonucunda elde edilen çıktı, yani üretimdir (Marx, 2014, s. 26). Kapitalizmde bu çerçevede bir kapitalistin, henüz ortaya çıkmamış bir emeği, yani bir emek ihtimali olan, belirsiz bir nitelik taşıyan emek gücünü satın alması söz konusudur (Thompson, 1989, s. 123). Üretim girdilerinden sermaye ve hammadde, 'değişmez sermaye' niteliğindeyken, emek gücü 'değişken sermayedir' ve "Bu kısım, kendi değerine eş bir değeri yeniden üretir buna ek olarak değişebilen, daha büyük ya da daha küçük olabilen bir fazlalık, yani artık değer üretir" (Marx, 2013, s. 210). Artık değerin kaynağı konumundaki değişken sermaye, insanın yaratma potansiyeli, iradesi ile ilişkilidir ve sermaye açısından kontrol altına alınması gerekli görülen bir unsurdur (Nichols, 1980, s. 34). Emek gücünün alıcisı ve satıcisı konumundaki kişilerin çıkarları, emek-sermaye ikiliği temelinde karşıt konumdadır. Bu karşıtlık, emekçinin potansiyelini ortaya koyması durumunda belirleyici olabilmektedir. $\mathrm{Bu}$

SEFAD, 2019; (42): 291-322 
çerçevede emek sürecinde 'kontrol' yani emekçi ve işveren ayrımında, emek sürecinin kontrolünün kimde olduğu, stratejik bir öneme sahip olmaktadır (Reid, 2003, s. 560).

İnsanın üretimi, zihinde çizilen bir tasarı ile bu tasarının uygulamaya geçirilmesi süreçlerinin birlikteliğinden oluşmaktadır. Emek süreci, çalışanın zihninde oluşan bu tasarı ve tasarının somut bir çabaya dönüşmesinden ibarettir (Marx, 1999, s. 27). Üretimi yapan kişi, üretime ilişkin tasarım ve uygulama süreçlerini bir bütün olarak işe koşmaktadır. Braverman (2008), kapitalist işbölümü sonucunda emek sürecinde, emekçide bulunan zanaata ilişkinin bilginin yönetime aktarıldığı, tasarım ve uygulamanın birbirinden ayrıldığı, çalışanın vasıfsızlaştırıldığı ve kontrol altına alındığını ve çalışanların birbirinin yerini doldurabilecek parçalara indirgendiğini savunmaktadır. Bu çerçevede Taylorizm ve ona temel oluşturan bilimsel yönetim anlayışı, emek sürecinde emek gücünün maksimum potansiyelini kontrol altına alma yönündeki bir kontrol stratejisi olarak öne çıkmaktadır. Braverman (2008, s. 132) bilimsel yönetim anlayışını şöyle özetlemektedir:

\section{"Böylelikle, ilk ilke emek sürecinin bilgisinin bir araya getirilmesi ve geliştirilmesi; ikinci ilke, söz konusu bilginin işçiler arasında mevcut olmaması biçimindeki yaşamsal karşıtıyla birlikte, bu bilginin uygulamacı alan olarak yönetimde yoğunlaştırılmasıysa, üçüncü ilke de, bilgi üzerindeki bu tekelin emek sürecinin her bir adımını ve uygulama tarzını denetlemek üzere kullanılmasıdır".}

Frederick W. Taylor (1997), bilimsel yönetimin temelinde, işçi ve yönetimin çıkarlarının bütünleştirilmesi olduğunu savunmaktadır. Böylelikle, emekçi, emek gücünün maksimum potansiyelini ortaya koymaktan çekinmeyecek ve maksimum verimlilik ilkesi temelinde emek gücü emeğe dönüşecektir. İşçinin maksimum verimlilikle çalışmaması Taylor'a göre, "sistematik kaytarma" sonucu gerçekleşmektedir: "Sistematik kaytarmanın büyük bölümü ise, daha hızl çalışmanın nasıl gerçekleştirilebileceği konusunda işverenlerini bilgisiz bırakmayı hedefleyen işçilerce yapılmaktadır" (s. 25). Taylor, işçilerin ellerinde tuttukları işe ilişkin bilgiyi işveren ile paylaşmayarak bu bilgiyi işten 'kaytarmanın' bir aracı olarak kullanabildiklerini savunmaktadır. Bu anlamda emek sürecinde kontrolün sağlanması adına işe ilişkin bilginin, zanaat bilgisinin işverene, yönetime aktarılmasının büyük önem kazandığı görülmektedir.

Kitlesel üretimin söz konusu olduğu 20. Yüzyllının ilk üç çeyreğine egemen olan Fordist üretim örgütlenmesinde, bilimsel yönetim ilkelerinin uygulanması ile doğrudan gözetim, görevlerin parçalanması, standartlaştırma, otomasyon ve bürokratik süreçler önem kazanmıştır. 20. Yüzyılın son çeyreğinde ise Post-Fordist olarak adlandırılan esnek üretim süreçlerinin yükselişi söz konusu olmuştur (Crowley, Tope, Daniel, Chamberlain ve Hodson, 2010, s. 422). Toyotizm olarak da adlandırılan Post-Fordist üretimde, kalite yönetimi, kalite çemberleri, kaizen gibi uygulamalar öne çıkmıştır (Kahveci ve Nichols, 2006, s. 5). Post-Fordizm, Fordist üretimde yaşanan karlılık krizine bir yanıt olarak ortaya çımıştır ve bu sistem, yeni tekniklerin uygulamaya koşulduğu, üretim süreçlerinde esnekliğin arttırıldığı bir emek örgütlenmesi olarak ele alınmaktadır (Köse ve Öncü, 2000, s. 79).

Crowley ve diğerleri (2010, s. 423), bazı düşünürlerin Post- Fordizm'in, Fordizm'den bir kopuş olarak görülemeyeceğini; Fordizmin, emek sürecinde standartlaştırma, verimlilik, işin yoğunlaştırılması ve kontrol gibi rasyonel fikirlerinin 'yeni teknikler' yoluyla PostFordist dönemde uygulamaya koyulduğunu savunduklarını belirtmektedir. Yazarlar, bu 
fikirlere katılmakla birlikte bir adım ileriye gitmekte ve esnek üretim yöntemleri yoluyla, Fordist üretim örgütlenmesinin temelinde yer alan, fakat bu dönemde tam anlamiyla uygulamaya konulmamıs, Taylor'un bilimsel yönetim ilkelerinin, Post-Fordist dönemde teknolojik gelişmelerle birlikte, uygulanabilir hale getirildiklerini belirtmekte ve bu anlamda Post- Fordizm yerine Neo-Taylorizm kavramını günümüzün üretim süreçlerini tanımlamakta daha uygun olacağını savunmaktadırlar.

Taylor'ın bilimsel yönetim ilkeleri, fabrika üretimine ilişkin bir dönüşümü öngörürken, bu ilkelerin birçok farklı alandaki emek sürecine uygulandığı görülmektir. Braverman (2008, s. 288), idari kadronun, üretim kadrosu karşısında sayıca fazlasıyla büyüdüğünden söz ederken, üretimin bir hayalet kopyası konumdaki büro işlerinin de yönetimin bilimsel-teknik devrim sonucu, standartlaşması ve rasyonelleşmesinin söz konusu olduğu belirtmektedir. Herdman (2012, s. 5), bilimsel yönetim ilkelerinin artan bir şekilde "akıl gerektiren işlerde" kullanılmaya başlandığını savunmaktadır. NeoTaylorizmde verimlilik teknoloji aracılığı ile arttırılırken, çalışanların bireysel çıktılarının performans denetlemesi yolu ile kontrol altına alınması söz konusudur. Ücretlendirmeler de artan bir şekilde bu performans denetimine bağlanmaktadır (Ünlütürk Ulutaş, 2011, s. 31).

Bilimsel yönetim ilkeleri, zanaat bilgisinin yönetime geçmesini sağlamakta, çalışanları vasıfsızlaştırmakta ve kolaylıkla yerleri doldurabilir hale getirmektedir. Kişilerin yerlerinin kolaylıkla doldurulabilir olması, iş güvencesinin ortadan kalkmasına sebep olmaktadır. NeoTaylorizmin yöntemleri yoluyla sağlanan esneklik, profesyonel üretim süreçlerinde de bir baskı unsuru olarak işlemektedir. İşsizlik tehdidi, geçici olarak dışarıya iş verme, proje bazlı çalışma, profesyonellerin performans ölçümleri yoluyla sürekli olarak kendilerini kanıtlamalarını gerektirmektedir (Crowley ve diğerleri, 2010, s. 425-429). İş güvencesinin ortadan kalktığı, yarı zamanlı çalışmanın yaygınlaştığı ve performansa bağlı çalışmanın egemen olduğu alanlardan birinin de akademik emek süreci olduğu söylenilebilir. Günümüzde profesyonel meslek olarak ele alınan ve bir zanaat yapısı taşıyan akademisyenliğin, bu anlamda nasıl bir dönüşüm geçirdiği tartışılacaktır.

\section{AKADEMIK EMEK SÜRECİNIN VE AKADEMISYENLIIĞİN DÖNÜŞÜMÜ}

Günümüzde, emek sürecine ilişkin tartışmalarda, kapitalist öncesi dönemde zanaatkarlığın 'ideal tip' olarak ele alındığı ve değişimin böylesi bir çalışma tipi üzerinden tanımlandığı görülmektedir. Zanaatkarlıkta, tasarım ve uygulamanın birlikteliği söz konusudur. Üreten kişi, ürüne yönelik bir çaba ortaya koyarken hem ürünün nasıl üretileceğini zihninde tasarlamakta, hem de bu tasarıyı uygulamaya koymaktadır. $\mathrm{Bu}$ anlamda emek sürecinin iki temel öğesi birbirinden kopmamıştır ve kontrol zanaatkarın elindedir (Braverman, 2008, s. 124). Mills (1969, s. 220) zanaatkarlığın özelliklerini şöyle tanımlamaktadır:

\footnotetext{
“Çalışmada, ortaya konulan üründen ve bu ürünün yaratım sürecinden farklı bir amaç söz konusu değildir. Günlük çalışmanın detayları, çalışanın zihinsel tasarımı ve çalışmanın ürünü birbirinden kopmamış olduğu için, anlamlıdır. Çalışan, kendi çalışma edimini kontrol etmekte özgürdür. Böylelikle zanaatkar, işini yaparken ondan öğrenebilir ve uygulama esnasında becerilerini ve vasıfların kullanıp geliştirebilir. Çalışma ve oyun veya çalışma ve kültür birbirinden kopmamıştır. Zanaatkarın geçim aracı onun tüm yaşam biçimini belirler ve onun için bir ilham kaynă̆ıdır".
}

SEFAD, 2019; (42): 291-322 
Mills, sosyal bilimci üzerine odaklandığı yazısında, akademisyenlerin, özellikle sosyal bilimler alanındaki akademisyenlerin birer zanaatkar olduklarını savunmaktadır. Böylesi bir akademisyen için sosyal dünya, yani yaşam alanı ve mesleği arasında bir ayrım söz konusu değildir. İki alan birbirinden beslenmektedir. Gündelik yaşam deneyimi, akademisyenin entelektüel zanaatının temelidir. Böylesi bir zanaat için söz konusu olabilecek en kötü durum, özellikle araştırma finansmanı sağlama yönünde, planlar yapmaktır (2000, s. 195197). Mills'in 1969 yılında tanımladığı ve akademik emek sürecinde rasyonelleşme ve rutinleşmeye işaret edecek durumun, günümüzde dünya genelinde geçerli bir uygulama haline geldiği görülmektedir.

Tancred ve Sheriff (1985, s. 371-378), akademik emek sürecinin araştırma ve ders verme faaliyeti temelinde örgütlendiğini ve akademik işin bir zanaat olarak ele alınması gerektiğini savunmaktadır. Kişi işini aslen, yaparak öğrenmektedir. Bilimsel bir çaba sergileyen akademisyen ders vererek derse verme becerisini mükemmelleştirmekte, araştırma yaparak ve araştırmadan çıktılar üreterek de bir araştırmacı olarak becerilerini sürekli geliştirmektedir. Yazara göre, son dönemlerde akademisyenlerin artan bir şekilde iştigal oldukları idari işler ise işin yoğunlaştırılması temelinde bir 'kontrol' stratejisi olarak görülmelidir. Araştırma ve ders verme faaliyetlerinde, zanaat yapısının korunması durumunda bir birliktelik söz konusudur. Yazar, akademisyenlerin araştırma yoluyla, kendi hammaddelerini üreten zanaatkarlar olduğunu bu temelde savunmaktadır. Araştırma sürecinde yalnız olan akademisyen, edindiği bilgileri ders verme sürecine entegre edecek, böylelikle araştırma ve ders verme süreçlerinde bir birliktelik söz konusu olacaktır. Böylesi bir idealize edilmiş, zanaat olarak akademisyenlik tanımının, günümüzde kurumun ihtiyaçları temelinde örgütlenen ders faaliyeti için geçerli olamayacağı söylenebilir.

$\mathrm{Bu}$ çerçevede bir zanaat yapısı üzerine kurulmuş olan akademisyenlik mesleğinin yapısındaki değişimden söz edilmektedir. Miller (1996, s. 117-119) aynı şekilde, özellikle ders verme faaliyeti göz önünde bulundurulduğunda akademisyenliğin bir zanaat olduğunu savunmaktadır. Söz konusu faaliyeti kendi örgütleyen ve uygulama sırasında yalnız olan akademisyen genel olarak bu çerçevede meslek dışı denetimden uzaktır. Fakat bilimsel yönetim anlayışı ile verimlilik ilkeleri temelinde artan öğrenci sayıları, üniversitelerin değişen yapısı, akademisyenlerin ders verme faaliyeti; yani zanaatları üzerindeki kontrolü yitirmelerine sebep olmaktadır.

Roberts ve Dohanue (2000, s. 379), akademisyenlik mesleğini öğrenmeye ve yeni fikirler keşfetmeye yönelik bir istek, soru sorma ve bu sorulara cevap aramaya yönelik bir merak ile ilişkilendirmektedir. Akademik emek sürecinde yaşanan dönüşüm ile birlikte, "öngörülebilirlik, verimlilik ve kontrol" üzerine yapılan vurgu akademisyenlik mesleğini dönüştürmektedir. Akademik ilgi, çıtılar üzerine odaklanır hale gelmektedir. Evans (2007, s. 12) ise akademisyenliğin temel bir güdü olan merak üzerine kurulmuş olduğunu fakat bu durumun günümüzde geçersiz kılındığını belirtmektedir:

\footnotetext{
"Zihnin deneysel, meraklı, açık uçlu alışkanlıkları, iş kadar 'oyun'u da kapsar. Bir bilimcinin kendine yüklediği, yayımlandı̆̆ında belki de meyva vermeyecek, ama zamanın fark etmeden geçip gitmesini sağlayan bir iş için yataktan kalkmasını mümkün kılan budur. Yaşlı akademisyenleri, yetmiş seksen yaşlarında masalarının başına sürükleyen de budur".
} 
Yazara göre yükseköğretim alanında yaşanan değişimler, akademisyenlerin meraka ilişkin güdülerini bir boş zaman uğraşı, bir tür lüks haline getirmektedir.

Neoliberal politikalar temelinde üniversite finansmanının sorunsallaştırılması ve dış kaynaklara bağımlı hale getirilmesi, artan öğrenci sayıları, araştırmanın piyasa güdümlü bir etkinlik haline gelmesi, yeni yönetsel stratejiler çerçevesinde üniversitelerde idari faaliyetlerin merkezi bir konum kazanması temelinde birçok yazar üniversitelerin ticarileşmekte, akademik faaliyetlerin metalaşmakta olduğunu belirtmektedirler (Bok, 2007; Kılıç, 2013; Lynch, 2014; Nalçaoğlu, 1999; Parker ve Jary 1995; Tekeli, 2003). Dönüşmekte olan üniversite yapıları, üniversitelerde üretilen bilginin 'uygulanabilirliğini' öne çıkarırken, "keşif bilimi" yerine "uygulama biliminin" geçtiği görülmektedir (Kogan ve Teichler 2007, s. 10). Bu çerçevede, üniversiteler uygulamaya yönelik olan alanların stratejik önem kazandığı, akademik ilginin uygulanabilir olanla sınırlandırıldığı yerler haline gelirken, akademisyenlerin konumunun değişmekte; akademik faaliyetlerin temellendiği emek sürecinin de akademisyenlerin kontrolünden çıkmakta olduğu görülmektedir.

Pedro (2009, s. 424), üniversitenin dönüşümü temelinde akademisyenlik mesleğinin değişen konumuna ilişkin şöyle demektedir:
"Üniversiteler artık sadece, akademisyenlerin mesleki faaliyetleri sonucu üretilen ve iletilen bilginin bulunduğu yerler olarak algilanmamaktadırlar. Artı üniversite akademisyenin, ilginç bulduğu şeylerin araştırıldı ̆̆g, bilinilmesinin gerekli olduğunu düşündüğ̈̈ şeylerin öğretildiği yerler değildir. Üniversiteler artık, en önemlisinin araştırma ve öğretim olduğu birden fazla görevin gerçekleştirildiği merkezler olarak düşünülmektedir. Bunu yapmak için de akademik personele ihtiyaçları vardır...".

Pedro, akademisyenlerin, üniversitelerdeki merkezi konumlarını yitirmekte olduklarını belirtmektedir.

Günümüzde akademik işin artan bir şekilde esnekleştiği, güvencesizleştiği, üniversitelerde yarı zamanlı pozisyonların arttığı görülmektedir. Rajagopal ve Farr (1992, s. 319), Kanada'da yarı zamanlı akademisyenlerin sayıca arttığını belirtirken bu durumu akademik emeğin değersizleşmesi sürecinin bir parçası olarak ele almaktadırlar. Altbach, Avrupa'da daimi kadroya geçmeden tam zamanlı çalışan akademisyen sayısının büyük oranda artmış olduğu söylemektedir (1997, s. 321). Amerika'da 1975 yılında \%31,4 olan yarı zamanlı öğretim elemanı sayısı 2011 yılında \%51,4'e çıkarken, daimi kadroda bulunan akademisyen sayısı aynı yıllar için \%35,9'dan \%20,6'ya düşmüştür (Curtis, 2014, s. 4). Amerika Üniversiteli Profesörler Derneği verilerine göre 2015 yılında Amerika'da çalışan akademisyenlerin yalnızca $\% 30$ 'u daimi statüde (daimi statü adaylarını da kapsayacak şekilde) çalışmaktadır (American Association of University Professors [AAUP], 2017). Avrupa'nın en büyük yükseköğretim alanına sahip İngiltere'de ise akademisyenlerin \%54'ünün güvencesiz koşullar üzerine kurulmuş sözleşmeler ile çalıştığı belirtilmektedir. Sözleşmeler yıllık ya da dokuz aylık dönemleri kapsayabilmektedir (University and College Union [UCU], 2016, s. 1- 2).

Latin Amerika'ya bakıldığında güvencesizliğin boyutlarının büyüdüğü görülmektedir. Örnek olarak Arjantin'de yarı zamanlı çalışmanın büyük ölçüde artması ile çalışan akademisyenlerin sadece \%14'ünün tam zamanlı bir şekilde çalıştı̆̆ görülmektedir (Teichler, Arimoto ve Cummings 2013, s. 63). Altbach (1999, s. 8) Buenos Aires Üniversitesi Modelini ele almakta, bu üniversitede daimi statünün tamamen ortadan kaldırıldığını ve 
çalışanların \%20'den azının tam zamanlı olarak çalıştı̆̆ını ve fakülte öğretim üyelerinin (profesörler de dahil olmak üzere) yedi yıllık süreç sonunda mutlaka tekrardan değerlendirme sürecine dahil edildiklerini belirtmektedir. Dünya çevresinde daimi kadrolarda görülen azalma ile birlikte yarı zamanlı çalışmada, geçici işlerde büyük oranda artış görülmektedir.

Wojcicka Sharff ve Lessinger (1994, s. 14- 15), New York kentinde çalışan yarı zamanlı akademisyenler ile gerçekleştirdikleri görüşmelerin analizi temelinde üniversitelerde geçici işin artışı ile birlikte akademide bir "alt sınıfın" ortaya çıtığını belirtmektedirler. Yarı zamanlı çalışanlar düşük ücretler karşlığında yoğun bir iş yükü ile karşı karşıyadır. Uzun süren bir eğitim süreci sonunda akademisyen olan ve ders başına ücret alan bu kişilerin ders dışında da (derse hazırlık, araştırma, öğrencilerle görüşme...) uzun süreler çalışmak zorunda olduklarını belirten yazarlar, iki farklı modelleme yapmakta ve böylesi bir istihdam şeklinin kurumlar için dönemlik ders başına, ilk modelde 4.000 \$, ikinci modelde ise 10.000 \$’lık bir artık değer yarattığını belirtmektedirler. Akademik işte yaşanan bu dönüşüm "Akademik Sweatshop ${ }^{1 "}$ kavramı çerçevesinde ele alınmaktadır. Akademide iş güvencesi azalmakta, yarı zamanlı pozisyonların artışı gözlemlenmektedir. $\mathrm{Bu}$ durum yükseköğretimde Taylorizmin yükselişi ile birlikte gerçekleşmekte; akademik işte performans yönetimi anlayışı önem kazanmaktadır.

Taylorizmde işin ölçülebilirliği olgusu temel alınmakta, bu çerçevede performans denetimleri her alanda uygulanabilir hale gelmektedir (Ünlütürk Ulutaş, 2011, s. 31). Yükseköğretim alanında akademik iş artan bir şekilde standartlaştırılmakta, ölçümlenebilir hale getirilmekte ve bu çerçevede performans ölçümlerine bağımlı kılınmaktadır (Symth, 1995, s. 14). Araştırma temelinde yayın sürecinde performans sistemleri dergi etki faktörleri, atıf sayısı gibi performans kriterleri temelinde ölçümlenebilir hale getirilirken (Gendron, 2008; Gruber, 2014), ders verme sürecinde bir ölçümleme yöntemi olarak öğrenci değerlendirmelerinin önemi artmaktadır (Emery, Kramer ve Tian, 2003).

Kramer (2008, para. 4) “Akademik Emeğin Taylorizasyonu” başlıklı yazısında, Dünya Tarihi dersinde bir not verme işleminin bile nasıl standartlaştırılabileceğini göstermektedir. Yaz döneminde sadece sinav okumakla görevlendirilen akademisyenden, önceden belirlenmiş kriterler temelinde not verme işlemini gerçekleştirmesi istenmiştir: "Öğrenciler, tez sunmaktan bir puan, sorunun tümüne yönelik bir cevap vermekten bir ila iki puan, örneklendirmeden bir ila iki puan, direkt karşılaştırma yapabilmeden bir puan ve bu direkt karşılaştırmanın analizini yapabilmekten bir puan almaktadırlar". Bu kriterler temelinde, not verme işlemini gerçekleştiren akademisyenlerin yüzlerce sınav okuyabilmesi söz konusu olmaktadır.

Akademik işin standartlaştırılması ve ölçümlenebilir hale getirilmesi yönünde ele alınabilecek Avrupa'da ortaya çıkan bir başka gelişme ise Bologna Sürecidir. 1999 yılında 29 ülkenin katılımıyla imzalanan Bologna Bildirisi ile birbiriyle karşılaştırılabilir akademik derecelerin üretildiği ortak bir Avrupa yükseköğretim sistemi hedeflenmektedir (Çelik, 2012, s. 100) Brancaleone ve O'Brien (2011, s. 515- 516), Bologna Sürecini, Avrupa Birliği yükseköğretim alanında piyasa modelinin benimsenmesi, eğitimin metalaşmasının bir sonucu olarak ele almaktadırlar. Zeybek (2015, para. 19) ise sürecin soyut bir faaliyet olan

\footnotetext{
${ }_{1}$ Sweatshop teriminin karşılığı olarak "Terhane" kullanılmaktadır (Yıldız, Z., ve Yıldız, S. (2017). Kayıt Dışı Ekonomi Bağlamında, Dünya ve Türkiye'de Kayıt Dışı İstihdam, Terhaneler ve Çocuk İşçiler. KMÜ Sosyal ve Ekonomik Araştırmalar Dergisi, 19(32), 96-106).
} 
akademik faaliyetin sorunlu bir şekilde sayısallaştııılması anlamına geldiğini belirtmektedir. Standartlaştırma, ölçümleme ve bu temelde kontrol sağlamanın akademik emek sürecinde yaşanan değişimler çerçevesinde temel eğilimler haline geldikleri görülmektedir.

Akademik emeğin iş güvencesini yitirmesi, yarı zamanlı çalışmanın yaygınlaşması ile birlikte akademik faaliyetlerin artan bir şekilde standartlaştırıldığı ve süreklileştirilen bir performans ölçüm mekanizmasına tabi kılındığı görülmektedir. Performans ölçümleri, somut araştırma çıktıları ve öğrenci değerlendirilmeleri yolu ile gerçekleştirilirken, geçmişte ölçümlenemeyen faaliyetlerin de standartlaştırılarak kontrole tabi tutulmaları söz konusu olmakta; işe ilişkin bilgi, zanaat bilgisi, yönetim birimlerine aktarılmakta akademik emek sürecinde kontrol de üniversite yönetimleri ya da kurumlarına devredilmektedir.

\section{DÜNYADA VE TÜRKIYYE'DE YÜKSEKÖĞRETIMINN DÖNÜŞÜMÜ}

1980'li yıllarda tüm dünyada işlerlik kazanan neoliberal politikaların, yükseköğretim sistemlerinin dönüşümünde etkili olduğu görülmektedir. Neoliberal politika toplumsal tüm alanların piyasa ilişkileri temelinde, verimlilik ilkeleri çerçevesinde düzenlenmesi gerekliliğini ortaya çıkarmakta, devletin ekonomik faaliyet gerçekleştiği alanlardan çekilmesini öngörmektedir (Çavdar, 2013; Clarke, 2014; Crouch, 2014). Devletin sunduğu hizmetlerde ise neoliberal dönüşüm, yeni kamu yönetimi anlayışının (YKY) uygulamaya konulması yoluyla söz konusu olmaktadır. YKY anlayışı, devletin sunduğu hizmetlerin, özel sektörün kullandığı yöntemlerin, uygulanır hale getirilmesi yoluyla, etkinlik ve verimlilik ilkeleri temelinde yeniden örgütlenmesi gerekliliğini ortaya çıkarmaktadır. YKY' de kamusal hizmet bütçelerinde küçülmeye gidilirken, hesap verilebilirlik kavramı önem kazanmaktadır (Willis, Carryer, Harvey, Pearson ve Hendorson, 2017; Van der Sluis, Reezigt ve Borghans, 2017).

$\mathrm{Bu}$ çerçevede, dünya çevresinde yükseköğretim, kamusal bir hizmet olmaktan çıkmakta (Tilak, 2012 s. 29), kamusal bir hizmet olarak sunulduğunda da verimlilik ve etkinlik ilkeleri temelinde örgütlenir ve denetlenir hale gelmektedir (Dominelli ve Hoogvelt, 1996; Enders, De Boer, ve Weyer, 2013). Neoliberal gündem temelinde, küresel yükseköğretim alanında gerçekleşen değişimlere model oluşturan yükseköğretim sisteminin Amerikan Yükseköğretim sistemi olduğu görülmektedir. Bu durum yükseköğretim sistemlerinin Amerikanlaştırılması olarak adlandırılmaktadır (Itoh, 2002; Mollis, 2001). Amerikan sistemi tarihsel anlamda özel sektör ve üniversitelerin işbirliği üzerine kurulmuştur. Balaban (2012, s. 29), bu sistemde "en başından beri üniversitenin kurumsal yapısının bir şirket olarak" oluşturulduğunu belirtmektedir.

Altbach (2001, s. 11), dünyada birçok yükseköğretim sisteminin verimlilik ilkeleri temelinde işlerlik kazanan Amerikan sistemini model aldığını dile getirmektedir. Yazar, kredi sistemi, devlet üniversiteleri ve özel üniversitelerin bir arada ve rekabetçi bir şekilde varoluşunun, kurum içi ve kurumlar arası hesap verilebilirlik anlayışının, kurumlar temelinde belirlenen ve kurumdan kuruma değissen vizyon ve hedeflerin, model konumundaki Amerikan sisteminin temel özellikleri olduğunu belirtmektedir.

Türkiye Cumhuriyeti'nin ilk yükseköğretim kurumu, 'Üniversiteler Reformu” kapsamında, Osmanlı İmparatorluğu döneminde 1863 yılında kurulmuş Darülfünün'un kapatılması ile birlikte 1933 yılında açılan İstanbul Üniversitesi'dir. Yükseköğretim Kurulunun (YÖK) kurulmasına kadar geçen sürede, sayı olarak artan üniversiteler devlet kurumları olarak işlev göstermiştir (Atalay, 2017a, s. 51). 1981 yılında 2547 sayılı kanunun 
kabulü ile YÖK kurulmuş ve Türkiye'de yükseköğretimden sorumlu tek kurum haline gelmiştir ("Tarihçe", t.y.). Yükseköğretimde merkezi otorite konumuna geçen YÖK, bu alandaki neoliberal gündemin uygulayıcısı olarak ele alınmaktadır (Hız, 2010; Ulutürk ve Dane, 2011; Balaban, 2012; Coşar ve Ergün, 2015). Neoliberal dönüşüm çerçevesinde hem ders verme hem de araştırma faaliyetlerinde çıtılar temelinde ölçümlenebilir, değerlendirilebilir, iş dünyası modelinin geliştirdiği verimlilik ilkeleri temelinde örgütlenebilir, kendi içinde daha rekabetçi bir Türkiye yükseköğretim alanı ortaya çıkmaktadır.

Bu dönüşüme ilişkin atılan adımlardan ilki, vakıf üniversitelerinin kuruluşu olarak ele alınabilir. 1984 yılında Türkiye'nin ilk vakıf üniversitesi olan Bilkent Üniversitesi kurulmuştur (Erguvan, 2013, s. 183). Vakıf üniversitelerinin kurulması hem yükseköğretim alanına sermayenin girmesi hem de yıllardır devletin sağladığı kaynaklar yoluyla varlığını sürdüren devlet üniversitelerinin daha rekabetçi bir ortama dahil edilmeleri çerçevesinde önemli bir adım olarak görülebilir. Dünya yükseköğretim alanında gerçekleşmekte olan dönüşümün Türkiye'deki yansımaları gelecek yıllarda birçok sayıda vakıf üniversitesinin kurulması ile birlikte görünür hale gelmektedir. 2017-2018 yılı YÖK istatistiklerine bakıldığında Türkiye'de 129 devlet, 72 vakıf üniversitesinin bulunduğu görülmektedir ("Türlerine Göre Mevcut Üniversite", t.y.). Devlet Üniversitelerinde çalışmakta olan öğretim üyesi sayısı 63.881, vakıf üniversitelerinde ise 12.696'dır ("Öğretim Elemanları Sayısı", t.y.). Türkiye genelinde çalışmakta olan öğretim üyelerinin $\% 16,6$ 'sının vakıf üniversitelerinde istihdam edilmesi söz konusudur.

Türkiye'de 1975 yılında yükseköğretim sistemine kayıtlı olan öğrenci sayısı 64.498'dir (Çetinsaya, 2014, s. 44). 2017-2018 yılı yükseköğretim istatistiklerine bakıldığında ise kayıtlı öğrenci sayısının 7.560 .371 olduğu görülmektedir (“Öğrenci Sayıları”, t.y.). 42 yıllık süreçte öğrenci sayısındaki artışın çok büyük bir oranda gerçekleştiği görülmektedir. Öğrenci sayısındaki artışı, üniversite sayısındaki artış izlemiş, üniversite sayısı, vakıf üniversitelerinin kurulması ile birlikte büyük ölçüde yükselmiştir. Fakat vakıf üniversitesi sayısındaki artışın, yükseköğretimde devlet bütçesi kullanımında yeterli azalmayı sağlayamadığı görülmektedir. Günümüzde devlet üniversitelerinde kayıtlı 6.963 .903 öğrenci, vakıf üniversitelerinde ise 589.307 öğrenci bulunmaktadır ("Öğrenci Sayıları", t.y.). Vakıf üniversitesi sayısının yüksek olduğu görülse de var olan öğrenci sayısına bakıldığında vakıf üniversitelerinin Türkiye genelinde kayıtlı öğrencilerin $\% 7,8^{\prime}$ ine hizmet verdiği görülmektedir.

Dünya çapında yükseköğretimde, öğrenci artışı (yükseköğretimde kitleselleşme), neoliberal politikaların işlerliği ve bunu izleyecek şekilde öğrenci başına düşen harcamanın düşüşü söz konusudur (Pedro, 2009, s. 421). Türkiye İstatistik Kurumu 2017 yılı raporuna bakıldığında, Türkiye'de eğitime yapılan harcamanın en büyük kısmının $(\% 29,8)$ yükseköğretime ayrıldığı görülmektedir (Türkiye İstatistik Kurumu, 2017). 2017 yılı Organization for Economic Cooperation and Development [OECD] raporuna göre Türkiye eğitimde öğrenci başına yapılan harcamanın en çok arttığ ülkelerden biri olmuş fakat buna rağmen, 2014 yılı verileri temelinde bu harcamanın OECD ülkeleri arasında en düşüklerden biri (sondan ikinci) olması söz konusu olmuştur (OECD Türkiye, 2017, s. 3- 4).

Türkiye özellikle genç nüfusa sahip, yükseköğretime talebin yüksek olduğu ülkelerden biri olarak, yükseköğretimde finansman sorunu ile karşı karşıyadır. Bu finansman sorunu var olan üniversitelerde performans yönetimini stratejik hale 
getirmektedir (Coşkun ve Ünal, 2013, s. 41). Performans yönetimi, kaynak kullanımının iş dünyasının verimlilik ilkeleri temelinde, mümkün olan en az girdi ile en fazla çıtının sağlanması şeklinde tanımlanan optimum girdi/çıktı oranı üzerinden gerçekleştirilmesi anlamına gelmektedir. Türkiye'de üniversitelerden mali özerklik sağlama yolunda adımlar atması beklenmektedir. $\mathrm{Bu}$ temelde, 'girişimci üniversite' kavramının kullanıldı̆̆ı, üniversite- sanayi işbirliğinin öne çıkarıldığı görülmektedir (Özcan ve Çakır, 2016, s. 38).

Dünyada 'girişimci üniversite' modelinin benimsenmesi, iş dünyası kavramları olan verimlilik, hesap verilebilirlik, performans yönetimi anlayışının yükseköğretimde kullanılır olması, akademik kapitalizmin yükselişi olarak değerlendirilmektedir (Musselin, 2013; Rhoades, 2007). Neoliberal politikalar temelinde geçmişte kamusal hizmet kapsamında olan hizmetlerin özelleştirilmesi çerçevesinde ortaya çıkan vakıf üniversiteleri ve yeni kamu yönetimi çerçevesinde mali özerklik anlayışı üzerinden devlet üniversitelerinde girişimci üniversite modelinin ve verimlilik ilkelerinin benimsenmesi ve bu durumun akademik emek üzerindeki etkileri, Türkiye'de "Akademik Taylorizasyon" (Bingöl, 2012, s. 60) olarak ele alınmaktadır.

\section{TÜRKIYY'DE AKADEMIK TAYLORIZM, AKADEMIDE BİLIMSEL YÖNETIMİN YÜKSELIŞ̧i}

Yüksek öğrenci sayıları ve azalan kaynaklar (öğrenci başına harcama) üzerinden işlev göstermekte olan yükseköğretim kurumları, var olan kaynaklardan en fazla çıktının sağlanması yönünde, bilimsel yönetim ilkelerini benimseyebilmektedir. Verimlilik temelinde ortaya çıkan bilimsel yönetim anlayışında, çalışandan en yüksek verimin alınması, emek gücünün maksimum potansiyelinin elde edilir olması, emek sürecinde tasarım ve uygulamanın kopması, zanaat bilgisinin yönetici birimlere aktarılması ve performans temelinde emek sürecinin dış kontrole tabi olması, zanaatkarın yerinin doldurulabilir hale gelmesi ve iş güvencesinin sorunsallaştırılması, Türkiye'de akademik Taylorizasyon olarak ele alınabilecek gelişmelerdir. Türkiye'de yükseköğretimde bilimsel yönetim anlayışının yükselişi, iş güvencesinin azalması, var olan kaynakların (personelin) kullanımıyla daha fazla çıktı sağlanması, atama ve yükseltmelerde güncel ve açı bir sayısal performans sistemine gidilmesi, norm kadro uygulamaları yoluyla kaynak kullanımının denetlenmesi gibi somut belirli gelişmelerde yoluyla anlamlandırılabilir.

Türkiye yükseköğretim alanında, özellikle kariyerin başlangıcında iş güvencesinin azalmakta olduğu görülmektedir. Tüm araştırma kadrosu atamalarının 2018 yılı itibariyle 2547 sayılı kanunun 50d maddesi kapsamında yapılmasını öngören değişiklik ile birlikte, yıllık sözleşme ile atanan araştırma görevlilerinin ataması lisansüstü eğitim alıyor olmalarına bağlanmıştır ("YÖK'ten 50/d", 2017). Eğitim sürelerinin bitiminde araştırma görevlilerinin kariyerlerine ne şekilde devam edecekleri soru işareti haline gelmiştir. Durmaz (2017, s. 972) 50d statüsündeki araştırma görevlilerini, iş güvencesinden tamamen yoksun, kariyer gelecekleri belirsiz kişiler olarak ele almakta ve "akademinin prekaryası" olarak tanımlamaktadır.

Ayrıca 2018 yılında yayınlanan bir değişiklikle doktorasını bitirmiş araştırma görevlilerinin ders vermesinin önü açılmıştır. Bu değişiklik ile birlikte araştırma görevlisi 12

\footnotetext{
2 Prekarya, proleteryadan farklı bir şekilde tüm toplumsal güvence mekanizmalarından yoksun kalmış ve özellikle geleceğe dair tam bir güvencesizlik içinde olan yeni bir sınıf olarak tanımlanmaktadır. Bknz: Standing, G. (2015). Prekarya Yeni Tehlikeli Sınıf. İstanbul: İletişim Yayınları.
}

SEFAD, 2019; (42): 291-322 
saati geçen ders yükü olması durumunda fazladan 10 saatlik ders yükü için ek ücret alabilecektir ("2547 Sayılı”, t.y., s. 5366). Yükseköğretimde verimlilik sağlanması, optimum girdi çıktı oranına ulaşma temelinde bir değişiklik olarak ele alınabilecek uygulama yoluyla, doktorasını bitirmiş ve öğretim üyeliğine geçmemiş kişilerin 12 saate kadar ek ders ücreti almadan ders verebilecekleri ön görülmektedir.

Türkiye Yükseköğretim sisteminde daimi kadronun ön koşulu olan doçentlik unvanına erişimin ise 2015 yılındaki bir başka düzenleme ile daha açı ve güncel bir sayısal performans ölçümüne bağlandığı görülmektedir. Ekim 2016 itibariyle geçerli olan uygulama puanlama sistemi üzerine kurulmuştur (Demir, Cennet ve Özdemir, 2017, s. 13). Üniversitelerarası Kurul (ÜAK) doçentlik kriterleri, güzel sanatlar alanı hariç tüm alanlarda başvuru şartı olarak en az 100 puanın alınmış olmasını ve en az 90 puanın doktora sonrası çalışmalarda elde edilmiş olmasını öngörmektedir. Puanlama sisteminde, atıf, uluslararası kitap bölümü gibi çeşitli faaliyet alanlarından puan alma zorunluluğu da belirlenmiştir. (“Doçentlik Başvuru Şartları”, t.y.).

2018 yılında yapılan bir değişiklik ile de doçentlik unvanı başvuru koşulu olan dil puanı 55'e düşürülmüş ve sözlü sınav kaldırılmıştır. Üniversitelerin verdiği daimi kadro olan doçentlik kadrosuna ilişkin kriterlerin belirlenmesi ise üniversitelere bırakılmıştır. Üniversite dilerse sözlü sınav yapacak ve var olan unvan kriterlerine ek olarak kadro kriterleri belirleyebilecektir (Tuncer ve diğerleri, 2018, s. 1320).

Üniversitelerin, var olan performans kriterlerinde yeniden düzenlemeye gitmeleri ve rekabet odaklı bir yükseköğretim alanına uygun olacak şekilde, yurtdışında çalışma deneyimi ya da SSCI, SCI gibi endekslerce taranan dergilerde yayın yapma ve ayrıca sözlü sınavda başarılı olma gibi zorunluluklar temelinde ek kriterler ${ }^{3}$ belirlemeleri söz konusu olabilmektedir. Günümüzde akademik performans hem ÜAK tarafından güncellenmiş ölçütler hem de üniversitelerin kendi kriterleri temelinde değerlendirmeye tabi hale gelmiştir.

Türkiye'de yükseköğretim, büyük ölçüde devlet tarafından finanse edilmekte ve bu temelde devlet politikaları ve günümüzde de yeni kamu yönetimi anlayışı temelinde değişim göstermektedir. Verimlilik ilkeleri çerçevesinde kamu personeli yönetiminde gerçekleştirilmesi planlanan değişikleri Başbakanlık tarafından, 2003 yılında yayınlamış raporda görmek mümkündür:

“Devlet Personel Rejimi Reformu ile bütün kamu kurum ve kuruluşlarında norm kadro uygulamasına geçilecek; Göreve alma ve yükselmede objektif kriterler getirilecek, statüler azaltılacak ve benzer statüler arasındaki ekonomik ve sosyal farklılıklar giderilecek; Maaş ve ücret sistemi sadeleştirilecek ve dengesizlikler giderilecek, esnek çalışma usulleri getirilecek; Orta vadede performansa dayalı ücret sistemine geçilecek..." (Dinçer ve Yilmaz, 2003, s. 160).

\footnotetext{
${ }^{3}$ Buna örnek olarak Yıldız Teknik Üniversitesi'nin 19.07.2018 tarihinde yayınlanan sosyal bilimler alanında Doktor Öğretim Üyesi kadrosuna atanmaya ilişkin kriterleri şöyledir: "Lisansüstü çalışmaları esnasında veya doktora sonrası bilimsel araştırma yapmak için toplamda en az 6 ay yurtdışında bulunmak (en fazla üçe bölünebilir) veya yabancı dilde (İngilizce) ders verme yeterliğine sahip olmak ve En az biri SCI, SCI-E, SSCI veya AHCI kapsamındaki dergilerde yayınlanmış makale olmak üzere toplamda en az iki uluslararası yayın yapmış olmak". Aynı kurumda doçentlik kadrosuna atanmak için ise Doktor Öğretim Üyeliğine atanma koşullarını karşılama dışında "doçentlik unvanına sahip olmak ve Üniversitelerarası Kurul tarafindan belirlenecek jürilerce yapılacak sözlü sınavdan başarılı olmak" şartı aranmaktadır (http://www.apry.yildiz.edu.tr/images/files/aydek20182014.pdf).
} 
$\mathrm{Bu}$ anlamda, devlet üniversitelerinin bünyesinde devlet memuru olarak çalışan akademisyenlerin statülerinde ve çalışma şekillerinde değişimlerin söz konusu olması beklenmektedir. $\mathrm{Bu}$ anlayış temelinde, 2018 yılında yürürlüğe giren Norm Kadro uygulaması yükseköğretimde verimliliğin arttırılması, bilimsel yönetimin yükselişi yolunda atılan adımlardan bir diğeri olarak ele alınabilir.

Yükseköğretimde öğretim elemanı norm kadrolarının belirlenmesi ve kullanılmasına yönelik yönetmelik 02.11.2018 tarihinde Resmî Gazete'de yayınlanmış ve yürürlüğe girmiştir. Yönetmeliğe göre bir kurumda gerçekleştirilecek norm kadro planlaması, asgari kadro sayısının iki katına kadar yapılabilecektir. Norm kadro dışı kadro taleplerinde ise kurumun niceliksel (öğretim üyesi başına düşen öğrenci sayısı gibi) ve niteliksel özellikleri (ileri düzey araştırma ve geliştirme faaliyetleri gibi) göz önünde bulundurulacaktır (“Devlet Yükseköğretim Kurumlarında", 2018).

Araştırma görevlisi atamalarının geçici kadro temelinde gerçekleştirilmesi, doktorasını bitiren araştırma görevlilerinin ders verebilmesi, doçentlik unvanının verilmesinde açık kriterler temelinde sayısal bir güncellemeye gidilmesi ve norm kadro düzenlemesi, yeni kamu yönetimi temelinde Türkiye'de yükseköğretimde bilimsel yönetimin yükselişi, Taylorizm olarak ele alınabilecek gelişmelerdir. Taylorizmin üzerine kurulmuş olduğu, işin ölçülebilirliğini ve böylelikle denetlenebilirliğini sağlama olgusu tüm dünyada akademik üretimde yayın temelinde sayısallaştırma eğilimi, yani niceliğe yapılan vurgunun artışını getirmektedir. Bu temelde akademik üretimde sayısallaştırmanın yöntemleri ve sorunları üzerinde durulacaktır.

\section{YÜKSEKÖĞRETIMDE PERFORMANS YÖNETIMİ, ENDEKSLERINN ANLAMI VE SAYISALLAŞTIRMA}

De Angelis ve Harvie (2009), 1970'ler itibariyle Neo-liberal politikaları Avrupa yükseköğretim sisteminde en fazla benimseyen kurumlar olan İngiliz Üniversitelerinde, akademik emeğin nasıl ölçümlenebilir hale getirildiğini tartıştıkları makalelerinde bu durumu 'Bilişsel Kapitalizm' kavramı çerçevesinde ele almaktadırlar. Yazarlar, akademik performans yönetimi anlayışını, akademik üretimin 'nasıl', 'ne kadar miktarda' ve 'ne kadar sürede' soruları üzerinden bir bilimsel yönetim anlayışı temelinde örgütlenişini, Taylorizmin akademideki yansıması olarak değerlendirmişlerdir. De Angelis ve Harvie (2009, s. 38), akademide yayın sürecini kontrol eden önemli bir pazarın, yayımcılık endüstrisi olduğu belirtmekte ve yayımcıların, 2006 yılında elde ettikleri büyük kar oranlarını ele almaktadır:
“Wiley, bilim, teknoloji ve sağhlk yayınlar \%45,5 oranında ve onun alt grubu olan ve daha çok sosyal bilimlere yönelik yayımcılık yapan Blackwells \%28,1 oranında bir faaliyet karn elde etmiştir. Hem dergi hem de kitap yayımlayan Taylor and Francis'in akademi ve bilim yayınları departman \%28,1 oranında, The Thompson Corporation ise sağlık ve bilim yayınları bölümünden \%24 oranında faaliyet karı kazanmıştır."

Akademide ölçümlemenin kazananlarından birinin yayımcılık endüstrisi olduğu görülmektedir. Performans yönetimi temelinde ele alındığında bu yayınevleri tarafından çıarılan dergilerin yüksek performans puanlarına karşılık gelecek (SSCI, SCI...) endekslerce taranması söz konusudur. Prestijli dergiler olarak ele alınabilecek bu mecralarda makale ret oranlarının oldukça yüksek olduğu görülmektedir. Gruber (2014, s. 167) böylesi dergilerin bilinçli bir şekilde, az bulunur olmadan kaynaklı talep artışı sağlamak üzere, dergi alanlarını kısıtlı tuttuklarını belirtmektedir. 
Tenür, yani daimi kadroya geçişin zorlaştırılması, iş güvencesinin sorunsallaştırılması ve verimlilik ilkeleri temelinde performansa bağlı kılınması sonucunda ortaya çıkan yayın yapma çabasının sonuçlarını Lattier (2016, para. 2) ele almaktadır: "İnsan bilimleri alanında yayınlanan makalelerden \%82'si bir adet atı bile almamaktadir; atıf alan makalelerden \%20'si okunmuştur; yazılan akademik makalelerin yarısı yazarları, hakemler ve dergi editörleri dışında kimse tarafindan okunmamaktadır". Ortalama olarak bir dergi makalesinin 10 kişi tarafından okunduğu belirtilmektedir (Biswas ve Kirchherr, 2015, para. 6).

Lattier (2016, para. 6), profesörlerin neden kimsenin okumadığı “saçmalıkları" yazdığ sorusunu sormakta ve nedenin, hakemli dergilerde yapılan yayınlarla birlikte sağlanan iş güvencesi olduğunu savunmaktadır. Yazar, dünya çapındaki yayın patlamasını bir profesör arkadaşının sözü üzerinden değerlendirmektedir: "Yaratıcı intihal". Akademisyenler, daha fazla yayın yapmak adına geçmişte gerçekleştirdikleri araştırmalar üzerine yeni kuramsal bakış açları geliştirmekte ve entelektüel sermayelerini kimsenin sormadığı, ilgilenmediği ve okumadığı soruların yanıtlarını aramak üzere harcamaktadırlar.

Günümüzde dünya çevresinde, akademisyenlerin rekabet edebilirliklerini belirlemek üzere kullanılan önemli bir ölçümleme yöntemi yayınların 'Etki Faktörü'dür. 1972 yılında Eugene Garfield, son 2 yılda bir yayına yapılan atıf sayısının ortalamasını almak suretiyle hesaplanan etki faktörünü ortaya koymuştur. Günümüzde Thomson Reuters tarafından dergi etki faktörü raporları yayınlanmaktadır (Vanclay, 2012, s. 2). 1970'li yıllarda kütüphanelerin hangi dergilere abone olacaklarını belirlemek üzere kullandıkları ve bu temelde önem kazanan ölçümleme yöntemi (Curry, 2012, para. 2) günümüzde dergilerin prestijini belirleme aracı hale gelmiştir (Gruber, 2014, s. 167).

Seglen (1992) dergi etki faktörünün sorunlu olduğunu göstermektedir. Ortalama olarak bir dergiye yapılan atıfların yarısı, dergide yayınlanmış makalelerin \%15'ine yapılmaktadır (1992, s. 631). Yani derginin etkisini gösterdiği öne sürülen sayı aslında dergide yayınlanmış az sayıda makalenin aldığı atfı göstermektedir. Etki faktörü kendine yapılan atıfları da içermektedir ve editör yazıları genellikle dergide yayınlanmış makalelere atıf yaparak bu sayıyı yükseltebilmektedir. Vanclay (2012, s. 226) şöyle bir örnek vermektedir: "Molecular Ecology yakın zamanda kendine 179 atıf içeren bir editör yazısı yayınlamıştır". Al ve Soydal (2012, s. 702), atıf anormallikleri nedeniyle Dergi Etki Faktörü Raporlarından çıkarılan dergi sayısının 2007-2011 yılları arasında 7'den 51'e çıktığını belirtmektedirler. Bu durum da sorunlu bir sayısallaştırma yönteminin yaygın bir şekilde ölçüm yöntemi olarak tercih edilmesiyle, kendine atıf gibi yanlış kullanımların da yaygınlaştığını göstermektedir

Böylesi sayısallaştırma araçları ayrıca alanlar arası ve ülkeler temelinde farklılıkların da göz ardı edilmesine sebep olmaktadır. Örnek olarak Tonta (2014, s. 7) Sosyal Bilimler alanında yayınlanan dergilerin etki faktörlerinin Fen Bilimlerine göre çok daha düşük olduğunu belirtmektedir. Bu durumun sebebi yazara göre sosyal bilimlerde bilimsel yayınlarda kitapların ağırlıklı olmasıdır. Dergi etki faktörlerinin kullanımına ilişkin sorunları listeleyen Seglen (1997, s. 499), veri tabanının İngilizce dili üzerine kurulmuş olduğunu ve Amerikalı yayıncıların egemenliği altında olduğunu belirtmektedir. Bu durum da Türkiye gibi ülkelerden etki faktörü yüksek dergilerde yayın yapmanın daha güç olacağı anlamina gelebilecektir. 
Atıf söz konusu olduğunda, bir makalenin çok sayıda atıf almış olmasının da tam anlamıyla makalenin önemine, olumlu etkisine işaret etmeyeceği söylenilebilir. Simkin ve Roychowdhury (2003, s. 273-274) oluşturdukları modeli kullanarak atıf yapılan makalelerin $\% 20$ 'sinin gerçekten okunmuş olduğu sonucuna varmışlardır. Gruber (2014, s. 169- 170) ise, bir makalenin eleştirilmek üzere de atıf alabileceğini, bazı inceleme makalelerinin orijinal çalışmadan daha fazla atıf aldığına ve ayrıca dergilerin fazla sayıda atıf alacağı düşüncesiyle yöntem makalelerini yayınlamayı tercih ettiklerini belirmektedir. Yazar, metriklerin bu derece önem kazanmasının sahteciliğin önünü açacağını ve "me too" (ben de) biliminin yaygınlaşmasına sebep olacağını belirtmektedir. Gendron (2008, s. 99), ölçümlenebilir olana yapılan vurgunun artması ile akademik üretimde yüzeyselliğin ortaya çıktığını savunmaktadır. Akademisyenlerin birer "performans sergileyicisi" konumuna geçmekte, atıf alabilmek adına, daha popüler olan alanlarda araştırma ve yayın yapmayı seçmekte olduklarını, bu durumun da bilimde yenilik arayışının son bulması anlamına geleceğini belirtmektedir.

Bilimsel üretimde 'kaliteyi' belirlemenin güç olması, akademik emek sürecinin bir uzmanlık alan bilgisi üzerine kurulmuş olması, dış değerlendirmeye yönelik ortak kriterlerin ortaya çıkmasına sebep olmuştur (Seglen, 1997, s. 498). Günümüzde yükseköğretimde Neo-Taylorizmin yükselişi ile birlikte, kişinin ne kadar zamanda ne kadar çıktı ortaya koyacağı, dünya çevresinde kullanılan performans yönetiminin gereklilikleri çerçevesinde belirlenir hale gelmektedir. Fakat bu performans yönetiminin sayılara odaklanması, içeriğin ve bu temelde akademik üretimin, bilimin kendisinin ikincilleşmesi, aracın amaç haline gelmesi, sayının insandan önemli konuma geçmesine sebep olabilmektedir.

Donald (2013) performans baskısına yönelik bloğunda bir editörün sözlerini paylaşmaktadır: "Doktora sonrası [araştırmacılarımızın] birçoğu kariyerleri açısından, yüksek prestijli bir dergide yayın yapmanın, bilim yapmaktan daha önemli olduğunu düşünüyor" (2013, para. 4). Curry (2019, para. 2) ise şöyle demektedir: "[Sayısal] Göstergeler belirli bir derecede öneme sahip bilgi sağlasa da bu bilginin sağladığı faydayı değerlendirmek zordur. Sayıları, olduklarndan fazla bir şeymiş gibi görmememiz gerektiğini, karmaşık insan faaliyetlerinin [kolaylıkla] sayılara indirgenemeyeceğini de göz önünde bulundurmalıyı".

Türkiye' de de performans yönetiminin, çıktı kontrolünün, temelde akademik yayınlar üzerinden gerçekleştirildiği görülmektedir. Tekeli (2003, s. 135), 'yayın yap ya da yok ol' anlayışının Türkiye'de akademik üretim açısından sayıca fazla ama içerik açısından sorunlu olan bir yayın anlayışına sebep olduğunu belirtmektedir. Mutioğlu (2016, s. 1013- 1014) ise performans baskısına ilişkin şöyle demektedir:

\footnotetext{
"Neo-liberal dönemde akademide ortaya çıkan gelişmeler, akademik emeğin metalaşması ve akademik emeğin Taylorizasyonu olarak tanımlanır. Yoğun ders yükü ve mesaiden arta kalan zamanlarda da neo-liberal akademinin yayın yap ya da yok ol dayatması nedeniyle sürekli yayın yapma baskısı duyan günümüz akademisyenleri, gerekli tüm koşulları yerine getirseler bile kendisini sürekli bir yetersizlik ve değersizlik hissiyle yüz yüze bulur veya performans fetişisti akademisyen profiline dönüşür".
}

Türkiye'de performans yönetimi kavramının yükselişi, Akademide Taylorizm ile birlikte yaşanan dönüşümde, nicelik açısından bir büyümeyi getirmiştir. Orer (2011, s. 135) 1980'lerin ikinci yarısından itibaren Türkiye kaynaklı bilimsel yayın sayısında büyük bir 
artış sağlandığını fakat etki faktöründe aynı derece bir yükselme söz konusu olmadığını belirtmektedir. Özellikle 2000'li yıllar ile birlikte, bilimsel yönetim anlayışı temelinde oluşturulan akademik atama ve yükseltme kriterlerinin güncellenmesi ile yayınlarda niceliksel artış hızlanmıştır. 1980-2004 yılları arasında yayın sayılarını ele alan Ak ve Gülmez (2006, s. 27), bu yıllar arasında yapılan yayınların \%57.7'sinin 2000-2004 yılları arasinda gerçekleştirildiğini belirtmektedir. Son 5 yılda, 1980-2000 yılları arasında yapılan yayın sayısına eşdeğer bir yayının ortaya çıktığını görülmektedir. Bu durum, üniversite ve akademisyen sayılarında artışı ile birlikte performans yönetiminin bir sonucu olarak ele alınabilir.

Türkiye'de yükseköğretimde Taylorizm'in yükselişi ile birlikte, performans yönetiminin ortaya çıkması, akademik emek gücünün maksimum potansiyelini gerçekleştirmesi yönünde çeşitli sayısal ölçütler temelinde değerlendirmeye tabi tutulması, akademik emeğin ders verme ve idari faaliyetleri üzerinden değil, büyük ölçüde akademik yayınları üzerinden değerlendirilmesi, yayınlarda niceliksel bir büyümeyi getirirken çeşitli olumsuz etkileri de beraberinde getirmiştir. Kaplan (2017, para. 6), ücret ödeyerek makale yayımlatma gibi uygulamalar yanında, Türkiye Çin Malezya hattında atıf çeteleri kurulduğunu belirtmektedir. Memurlar.net ("Atıf Çetesi", 2015) web sitesi de 'atıf çetesi' başlı̆̆ ile duyurduğu haberinde, fen ve sosyal bilim gibi farklı alanlardan birbirine atıf yaparak atıf ağı kuran Türkiye menşeili 5 derginin Web of Science veri tabanından çıkarıldığını yazmaktadır.

Sayısallaşmanın artışı ile birlikte, bilimsel etiğin göz ardı edildiği uygulamaların ortaya çıkışı YÖK'ün de dikkatini çekmiş, YÖK başkanı Prof. Dr. Yekta Saraç'ın önerisi üzerine ÜAK yağmacı (predator) ${ }^{4}$ dergilerde yapılan yayınların doçentlik başvurularında kullanılamayacağı kararını almıştır. YÖK başkanı, sayısal anlamda Türkiye'de yapılan yayınların yeterli olduğunu fakat nitelik açısından aynı şeyin söylenemeyeceğini belirtmiştir ("Yağmacı Dergi",2019).

Sayıların tek hedef haline gelmesi, bilimin kendisinin ikincil konuma düşmesi, yayınların araç değil amaç konumuna geçmesi; kimse tarafından okunmayan yayınların, "ben de" biliminin yaygınlaşması, dünya çevresinde ve Türkiye'de yükseköğretim sistemlerinde dönüşüm ve akademik emeğin Taylorizasyonu ile birlikte ele alınabilecek gelişmelerdir.

\section{AKADEMISYENLIKK MESLEĞİNIN DEĞIşìiMi: SOSYAL BİLIMLER ÖRNEĞí SAHA ÇALIŞMASI}

Neoliberal politikalar, yükseköğretimde metalaşma ve akademik emeğin Taylorizasyonu süreçlerinin Türkiye'deki yansımalarını anlamlandırmak üzere gerçekleştirilen doktora çalışmasının saha aşaması 2017 yılında tamamlanmıştır. Akademik emek sürecinde yaşanan değişimleri anlamlandırmak üzere, derinlikli bilgi elde etme isteği temelinde çalışma, niteliksel bir metodolojik temele oturtulmuştur. Bu çerçevede, çalışmanın kuramsal temelini oluşturan 'Emek Süreci Kuramı' (Braverman, 2008) temelinde yarı yapılandırılmış bir derinlemesine görüşme formu hazırlanmış ve bu çerçevede İstanbul ve İzmir illerinde yer alan devlet ve vakıf üniversitelerinin sosyal bilimler alanlarında çalışan 28 öğretim üyesi ile derinlemesine görüşme gerçekleştirilmiştir (Atalay, 2017b).

${ }^{4}$ Yağmacı dergi kısaca, ücret karşılığı yayın yapılan ve akademik usule uygun yayın yapılmayan dergi olarak tanımlanmıştır (YÖK, 2019). 
Akademik emek sürecinde yaşanan dönüşüm, farklı bilim alanlarında yaratılan ekonomik fayda temelinde bölümlerin piyasa değerlerinin değişim göstermesi çerçevesinde farklı şekillerde gerçekleşmektedir. Bu çerçevede hem kendi içinde karşılaştırmaya imkan sağlayacak bir örneklem üzerinden çalışmayı yürütmek hem de araştırmacının kendisinin sosyal bilimler alanına ilişkin önbilgiye sahip olması dolayısıyla araştırma, sosyal bilimler alanlarında çalışan akademisyenler ile gerçekleştirilmiştir. Çalışmanın evrenini, arkeoloji, antropoloji, coğrafya, felsefe, psikoloji, sosyoloji, tarih, sanat ve bilim tarihi bölümlerinde çalışan akademisyenler oluşturmuş; coğrafya, felsefe, psikoloji, sanat tarihi, sosyoloji ve tarih bölümlerinde çalışan akademisyenler ile görüşmeler gerçekleştirilmiştir.

Araştırma, yükseköğretimde metalaşmanın etkilerini değerlendirme saiki ile vakıf üniversitelerinde çalışan öğretim üyelerinin çalışma deneyimini merkeze almıştır. Bu çerçevede Türkiye'de en fazla vakıf üniversitesi sayısına sahip ve sermayenin merkezi konumundaki şehir olan İstanbul ilinde çalışma deneyimi temel alınmıştır. Sermaye yoğunluğunun daha düşük olduğu, az sayıda vakıf üniversitesinin bulunduğu İzmir ilindeki küçük ölçekli akademik üretim alanı da farklı bir çalışma deneyimini anlamlandırmak üzere çalışmaya dahil edilmiştir.

Çalışmanın örneklemi belirlenirken, maksimum çeşitlilik örnekleme ve kartopu örnekleme teknikleri kullanılmıştır (Glesne, 2015:61). Bir amaçlı örnekleme yöntemi olan maksimum çeşitlilik örneklemesi ile öğretim üyesi başına düşen öğrenci sayıları (iş yoğunluğu), üniversite sıralamaları (üniversitenin tercih edilirliği-prestij), üniversitelerin kuruluş yılları (kurumsallaşma) gibi kriterler temelinde örneklem belirlenmiştir. Bu temelde daha güvencesiz çalışma koşullarına tabi oldukları düşüncesi temelinde örnekleme daha fazla sayıda yardımcı doçent unvanlı öğretim üyesi dahil edilmiş, aynı şekilde vakıf üniversitelerinde çalışan akademisyenlerle daha fazla sayıda görüşme yapılmıştır. Çalışmanın Olağanüstü Hal döneminde gerçekleştirilmesi, derinlemesine görüşmenin temelinde yer alan güven ilişkisinin tesisinde sorun olarak kendini göstermiş bu çerçevede kartopu örnekleme de kullanılmıştır. Gerçekleştirilen 28 görüşmeden 20'si İstanbul ilinde, 8'i İzmir ilinde; 19'u vakıf üniversitesinde 9'u devlet üniversitesinde; 16'sı Yardımcı Doçent, 7'si Doçent, 5'i Profesör Doktor unvanlı öğretim üyesi ile gerçekleştirilmiştir.

Yapılan görüşmeler sonucunda, akademik emek sürecinde Taylorizm'in yükselişi; performans yönetimi, müşteri konumunda öğrenci, teknolojik denetim gibi yöntemler aracılığıyla emek sürecinde dış kontrolün artışı; akademik işte tasarım ve uygulamanın ayrılması ve yoğunlaşma; akademik emeğin vasıfsızlaşması ve yeri doldurulabilir hale gelmesi; akademik işin güvencesizleşmesi gibi gelişmeler temelinde görünür olmuştur. Çalışmada, akademik emek piyasasının da akademik emeğin kontrolünde önemli bir rolü olduğu görülmüştür. İstanbul ilinde birçok üniversite bulunması, kişilerin kurumlar arası hareketliliğini arttırmakta ve güvencesiz koşullar karşısında bir dayanak noktası oluşturmaktadır. Örnek olarak Katılımcı 11 (Yrd. Doç. Dr. V5.)'in bulunduğu vakıf üniversitesi, çalıştığı beşinci kurumdur. Katılımcı 25 (Yrd. Doç. Dr. V.), bu konuda şöyle demektedir: "Ya bi süre daha ben şu mobilitenin [hareketliliğin] İstanbul'da iyi süreceğini düşünüyorum... Hani burda diyelim ki biz anlaşmadık, dedik ki başka bi yere geçsem falan filan... Yani yeni bi yer bulmam çok uzun sürmez". İzmir ilinde az sayıda üniversite bulunması,

${ }_{5}^{5}$ V: Vakıf Üniversitesi; D: Devlet Üniversitesi. Araştırmanın gerçekleştirildiği dönemde, sonradan kaldırılan, Yardımcı Doçent unvanı kullanılmaktadır.

SEFAD, 2019; (42): 291-322 
kurumlar arası hareketliliği ve alternatifleri azaltmakta, bu çerçevede kişilerin var olan koşulları daha yıkıcı bir şekilde deneyimlemelerine sebep olabilmektedir.

Çalışmada öğretim üyelerinin bulundukları üniversitelerde birçok farklı faaliyeti bir arada yürüttüğü görülmektedir. Ders verme ve araştırma dişında akademisyenler, 'sekreterlik' hizmetlerini yerine getirebilmektedirler. Bir devlet üniversitesinden emekli olmuş Katılımc 8 ( Prof. Dr. V.) bu konuda şöyle demektedir: "Angarya işler diyebileceğgim, öyle tabir edilebilecek işler... Bölümlerin [sekreterleri] olmadığı için, gençler sekreterlik işlerini de yapıyorlar. Yani araştırma görevlileri, alt kadrolar, yardımo doçentler, doçent arkadaşlarım bile, devletteki arkadaşlara göre çok daha yoğun çalışıklarını görüuorum". En az sayıda kişi ile en fazla çıktının elde edilmesine yönelik bilimsel yönetim anlayışının, akademik işin yoğunlaştırılmasında etkili olduğu görülmektedir. Öğretim üyelerinin, kurumda yeterince idari personel bulunmaması sebebiyle idari işleri de yerine getirmeleri söz konusudur. Aynı temelde yeterince akademik personelin bulunmadığı bir kurumda çalışan Katılımcı 15 (Yrd. Doç. V.), kendi vermediği farklı derslerin sınavlarında gözetmen olarak görev yaptığını belirtmiştir. İki durumda da Taylorizmin bir sonucu olarak, akademisyenliğin zanaat yapısısının bozulmasına işaret edecek şekilde, akademisyen ve emeği arasında kopma söz konusudur. Akademisyenler emek süreçleri üzerindeki kontrolü kaybetmekte, optimum girdi çıktı oranını gözeten kurumların öncelikleri temelinde hareket etmektedirler.

Akademik işin en yoğun olarak deneyimlendiği faaliyetin ders verme faaliyeti olduğu görülmektedir. Katılımcı 11 (Yrd. Doç. Dr. V.), bir dönemde 24 saatlik dersi olduğunu, Katılımcı 13, (Yrd. Doç. Dr. V) bir dönemde toplamda 900 öğrenciye, Katılımcı 20 (Doç. Dr. V.) 410 öğrenciye ders verebildiğini belirtmektedir. Katılımcı 19 (Yrd. Doç. Dr. V.) ise görüşmenin gerçekleştirildiği dönemde hazırlık yapmasını gerektirecek şekilde 7 yeni ders verdiğini söylemektedir. Aynı Katılımcı, vakıf üniversitelerinde kar sağlamak amacıyla, havuz dersi sisteminin uygulandığını böylelikle, en az sayıda öğretim üyesi ile en fazla sayıda öğrenciye hizmet verilebildiğini belirtmektedir: "Bu sayede şey daha çok kâr ediyolar. Birinci ve ikinci sinffların çoğu havuz. Yani sekiz yüz öğrenci dolayısılyla on tane hoca ve on tane ayrı ders on değişik şekilde bölümüne göre izlenebilecekken, sekiz yüz kişi tek hocadan bir derse girmiş oluyor işte, havuz oluyor dolayısılyla maksimum kâr".

Ders saatlerinin ve öğrenci sayılarının yüksekliği yanında vakıf üniversitelerinin çoğunluğunda finansman, öğrencilerden alınan ücretlerle sağlanmakta, bu durum da müşteri konumunda bir öğrenci profili yaratabilmektedir. Ders dışında öğrenciler, özellikle yeni iletişim teknolojileri yoluyla öğretim üyelerine ulaşmaya çalışmaktadırlar. Katılımcı 11 (Yrd. Doç. Dr. V.) öğrencilerin öğretim üyelerini gece üçte arayabildiğini, Katılımcı 6 (Prof. Dr. V.) öğrencilerin, e-maillerine hafta sonu gibi mesai saatleri dışında yanıt alma konusunda talepkar olabildiğini belirtmektedir. Ders verme faaliyeti temelinde ortaya çıkan iş yükü yanında öğrenci memnuniyeti kurumların en önemli hedeflerinden bir olurken, öğrenci yoluyla denetimin de temel bir mekanizma haline geldiği görülmektedir. Öğretim üyelerinin yetkinliğini sorgulayan öğrenci memnuniyet anketleri yanında vakıf üniversitelerinde doğrudan şikayet yönteminin de kullanıldığı görülmektedir.

Katılımcı 10 (Yrd. Doç Dr. V.) bulunduğu kurumda, bir öğrencinin e-mailine geç yanıt aldığına dair rektöre ilettiği şikayet sonucunda, öğretim üyesinin rektör tarafından uyarıldığını, Katılımcı 19 (Yrd. Doç. Dr.) öğrencilerin "derste bana sert baktı" şeklinde bir şikayeti idareye iletebildiğini belirtmektedir. Katılımcı 26 (Yrd. Doç. Dr. V.) ise şikayet mekanizmasının önemini şu şekilde dile getirmektedir: “Ama ee bi şikayet olursa ee direk olarak 
öğrenci şikayet ettiğinde dekan veya rektör direk hocayı çă̆ırıyo nedir bu iş, soruyor. Haksızsa soruşturma açabiliyor".

Öğretim üyelerinin, ders verme sürecine ilişkin yoğun iş yükü yanında birçok farklı görevi de yerine getirdikleri görülmektedir. Bu görevlerden biri üniversite tanıtımlarıdır. Bilimsel yönetim anlayışının bir yansıması niteliğinde, çalışandan maksimum emek elde etme itkisi temelinde, üniversitelerin 'reklam' faaliyetlerini de öğretim üyelerinin gerçekleştirdiği görülmektedir. Katılımcı 8 (Prof. Dr. V.) bu konudaki deneyimini paylaşmaktadır: "Illk geldiğim yıl Kadıköy'deki karavanda görev yaptım... Orada gelen geçen ee vatandaş merak edip soruyodu... Yani burda işte tanıtım yapmak durumunda kalıyosunuz, öğrenci çekmek durumunda kalıyorsunuz... Yani reklam faslı diyeyim...". Katılımc1 5 (Yrd. Doç. Dr. V.) kendisine saat 18:00 sonrasında, üniversiteden oldukça uzak ilçelerde tanıtım görevi verildiğini belirtmektedir. Birçok katılımcı üniversite tanıtımlarının kendilerini "yalan" söylemek zorunda bıraktığını belirtmektedir. Katılımcı 13 (Yrd. Doç. Dr. V.), bu konuda şöyle demektedir:

\begin{abstract}
“Bu sene mesela bir X[şehir adı]' e günü birlik tanttım gezisine gittim... ben buranın gerçek bir üniversite olduğunu falan da düşünmüyorum yani. Yani üniversite bu değil, böyle bir şey değil. Hatta diyorum ki en baştan zaten amacımız diplomayı satmak para karşılı̆̆ında, en başından bunu yapalım... Şimdi ben bu şekilde hissederken, öğrencilere gidip bu okulu tanıttı̆̆ım zaman yalan söylemiş söylüyorum yani yalan söylemek de istemiyorum, bu sefer bir şey söylemiyorum... Yani ben berbat hissediyorum açıķası... kendime yabancılaştı ̆̆ımı hissediyorum".
\end{abstract}

Akademik Taylorizm'in yükselişi ile bir arada gerçekleştirilen birçok faaliyet çerçevesinde iş yoğunluğunun artışı yanında katılımcıların büyük çoğunluğunun akademik iş ile akademik yayını özdeş tuttukları görülmektedir. Fakat günümüzde işin yoğunlaştırılması ve performans yönetiminin yükselişi sonucu katılımcılar tarafından, yayın süreçlerinde sayısallaştırma ve sahtecilik gibi olumsuz durumlara işaret edilmiştir.

Vakıf üniversitelerinde çalışan akademisyenler için akademik yayın sadece atama ve yükseltmelerde kullanılmamakta, güvencesiz koşulların bir sonucu niteliğinde, bazı durumlarda yıllık bazda yenilenen sözleşmelerin gerekliliği olabilmektedir. Bu temelde Katılımcı 2 (Yrd. Doç. Kadın, V) yayın yapma süreçlerini şöyle tanımlamaktadır:

\begin{abstract}
“Bu bir tür kendi ritmimi bulduğum bir süreç değil, sözleşme yenileme süreçlerine göre belirleniyor açıçası... Yani orda derdiniz şu kadar sürede makale yayınlamak mı yoksa şu nitelikte bir makale yayınlamak mı? ... Bir taraftan kafamda çok ilginç kurgular var 'Acaba' dediğim farklı şeyler var. Ama bunu bir kenarda tutuyorum... Onu erteleyip daha kısa daha hızlıca belki daha descriptive [betimleyici] diyebileceğim bir yazı çıkartmam gerekiyor ki, ben işte kalabileyim...".
\end{abstract}

Katılımcı, işini kaybetmemek adına daha hızlı yayın yapmanın yollarını aradığını belirtmektedir.

Birçok katılımcı günümüzde akademik işin başa çıkılması zor bir şekilde yoğun olduğunu dile getirmektedir. Katılımcı 5 (Yrd. Doç. Kadın, V.), eskiden yayınlarını daha fazla zamana yayarken bugün işlerini hızla yaptı̆̆ını belirtmekte ve şöyle demektedir:

"X hoca var yıllarca X'de [Devlet Üniversitesi] ders vermiş profesör, bana diyor ki 18 saat ders biz de verdik diyor, ben de diyorum ki siz de verdiniz ama sizde bir akademik

SEFAD, 2019; (42): 291-322 
yükseltme kriteri var mıydı? Bizde burada her şeyi beraber ol diyorlar, ben 18 saat ders de vereceğim, yılsonunda benden bir SSCI bir yayın bekliyorlar, aynı zamanda bir de şey öğrenciler de memnun olacak, böyle bir insan yok dünyada... Bunu dünyanın neresine giderseniz gidin söyleyin, böyle bir insan yok, hani 18 saat ders ver, öğrencin çok olsun, yayın yap, yok böyle bir şey. Arada mümkünse bir de Essay [açık uçlu sınav sorusu] de sor, bir de dersin asistanı da yok, yani bunu anca anca ... Sizden isteyecek olan insan... Yani o kadar işi anlamayacak, sizden böyle bir şeyi isteyecek".

Burada öğretim üyesi performans yönetiminin diğer akademik faaliyetler temelinde bir bilimsel yönetim anlayışı üzerinden planlanmamasına itiraz ekmektedir. Aynı Katılımcı kendi yayın stratejisini şöyle anlatmaktadır:

\begin{abstract}
"Yani en fazla, yani high impact journallarda [yüksek etki faktörlü dergi] yayınlanmış en fazla sayıda cite edilmiş [atıf almış] makaleleri o konudaki, okuyorum. Çok, to the point [hedefe yönelik]. Oralarda bir şey çıkartmaya çalışıyorum, ama daha çok zamanım olsa, o konudaki daha çok sayıda araştırma okuyup, daha izole araştırmaları da okuyup, daha geniş bir perspektiften bakmaya çalışırdım. Daha fonksiyonel pratik olmaya çalışıyorum zamansızlıktan dolayı".
\end{abstract}

Katılımcı 6 (Prof. Dr. Erkek, V.) ise akademik üretim sürecinde nicelik ve nitelik çelişkisine işaret etmekte ve şöyle demektedir: “... Örneğin bi insan var, beş tane indeksli yayın yapmış. Eem, güzel hoş bi insan var, beş yıl yayın yapmamış; o beş yıl birer yayın yapmış, yılda birer tane yapmış... [Diğeri] Beş yıl bi şey yapmamış ama bi yayın yapmış, uff acayip atıf almış, şey ee hangisi daha iyi?". Bu temelde akademik işin nitelik temelinde belirsiz, çelişkili doğasına işaret edilmektedir. Katılımcı 8 (Prof. Dr. Kadın, V.) de bu belirsizliğin alan temelinde ortaya çıtığını ve karşılaştırmayı sorunlu hale getirdiğini belirtmektedir: "Çok deneyimli, donanımlı olsa da hani bir profesör hoca... Çok fazla sayıda araştırmayı üstlenebilecek durumu olamaz. Yani insanüstü bir yaratık değil bu. E ama bunun sayısı ne olması gerekir derseniz onu bilemem. Alana göre de değişir". Katılımcı 22 (Doç. Dr. Erkek, D.) de, kendi alanında yayın yapmanın uzun bir sürecin sonucu olduğunu belirtmekte ve şöyle demektedir: "Yani bu işte ne biliyim işte, tıp doktorlarının çalışmalarına benzemez, mühendislerin çalışmalarına benzemez, iktisaţ̧ıların çalışmalarına benzemez. Dolayısıyla hani ee bizde çok böyle çok hızlı bi ürün çımaz...".

Katılımcı 10 (Yrd. Doç. Dr. Erkek, V.), kendi kurumunda kişi başına yılda iki makale şeklinde açık bir yayın hedefi olduğunu, böylesi bir performans yönetimi anlayışının, sayısallaştırmanın, akademisyenler üzerinde yarattığı baskının olumsuz etkilerine vurgu yapmakta ve şöyle demektedir "Yani bu üniversitedeki akademik üretim yönündeki baskı o kadar yüksek ki yani hani, bu kişilerin akademik üretimini negatif etkileyebilir... Hani o seviyeye ulaşamazsak sıkıntıya gireriz psikolojisi onları sıkıntıya sokuyor. Dolayısıyla akademik üretimdeki, belli bir matematiksel sınırlar ee işin bence doğasını bozan bir karaktere sahip".

Kariyerinin başlangıcında olan birçok katılımcı, performans sisteminin yıkıcı yönlerine vurgu yapmakta fakat mevcut konumlarını korumak adına, sistemin gerekliliklerini yerine getirdiklerini belirtmektedirler. Örnek olarak Katılımcı 12 (Yrd. Doç. Dr. Kadın, V), "Tabi ki benim de var böyle çabalarm, en nihayetinde bir oyunun içerisindeyseniz kurallarına uymak zorundasınız. Ha ama bunları çok büyük bir aşkla mı yapıyorum hayır ama yapıyorum" diyerek performans sistemini bir oyuna benzetmektedir. Günümüzde yeni kamu yönetimi anlayışı çerçevesinde devlet üniversitelerinde de akademik Taylorizmin yükselişi özellikle yayın yapma faaliyetinde görünür olmaktadır. Katılımcı 1 (Yrd. Doç, Erkek, D), 
"Yani dergi editörlü̈̆̈̈ yapıyorsunuz, hakikaten hakemlik sürecini yürütüyorsunuz, her şeyini yani Türkçesine kadar bakıyorsunuz ama şimdi illa Ulakbimde bilmem neye girmesi gerekiyor. İki şunu da yapmam gerekiyor hissi. Yani ben zaten bunları yapıyorum; sistem çok fazla bonus toplamaya... artık istediğiniz gibi okuyabilirsiniz... zorluyor" diyerek aynı sürece işaret etmekte ve performans ölçümüne yönelik çalışmayı bonus toplamaya benzetmektedir.

Katılımcı 15 (Yrd. Doç. Dr. Kadın, V) ise kariyerinde ilerlemek adına yurt içi yayınlara öncelik verdiğini belirtmekte ve yayın yapma sürecinde amaç- araç karmaşasına işaret etmektedir: "O yüzden yurtiçine yayın yaptım ama şimdiden sonra biliyorum ki, hani kitap bölümünün çok değgeri yok, daha çok yurtdışında iyi yerlerde yayın yapmanın büyük önemi var doçentlikte puan să̆lamak için. Ama şimdi böyle söyleyince şey şey oluyor, yine araç amaç birbirine giriyor". Katılımcı 9 (Doç. Dr. Erkek, V) da akademik ilerleme adına hızlı yayın yapma stratejisini paylaşmaktadır: "Biraz kariyerist denilebilir, ben biraz hızlı yayın yapıp, hızlı doçent olmaya çalışmıştım kendi açımdan.

Bunlara karşılık bir devlet üniversitesinden emekli, vakıf üniversitesi öğretim üyesi Katılımcı 7 (Prof. Dr. Kadın, V), uzmanlık konularında yıllarca çalışıp kolaylıkla kitap yayınlayamadığını fakat günümüzde bu durumun değiştiğini belirtmekte ve "Ee gencecik arkadaşlarımız X [Katılımcının Bölümü] doktorasını yapıyoo, doktoranın bir yıl sonrasında X teorileri kitabı yazıyoo. Ee bazen şaşırıyorum... Bu da ne oluyo, tekrarcılık, aktarmacılık, kopyeciliği de beraberinde getiriyo" demektedir. Katılımcı 20 (Yrd. Doç. Dr. Kadın, V) de performans sistemleri ile birlikte tekrarcılığın arttığını belirtmektedir: "Sonuçta bi doktora tezinden on yedi yayın çıkaran birini görmüş olmaktan sonra... ee demişti ki çünkü napıyim üniversitem istiyo demişti... Herkes bunu yapıyo çünkü artık bu şey gibi oldu aslında, bana pazarlama gibi geldi... Yayın yapıyo mu yapıyo, çok üretken hoca, evet... Ama aslında toplamda bi tane veri toplamış onları evire çevire yayın yapıyo".

Katılımcı 24 (Yrd. Doç. Dr. Kadın, V) böylesi bir sayısal temelde düşünme ve yayın yapma anlayışının günümüzde hakim olduğunu kabul etmekte fakat bu duruma uyum sağlayamadığını dile getirmektedir:

\footnotetext{
“İşte colerdeki makaleleri çok görüp aa çok iyiymiş demek yerine, üstünden geçiyorum, nerelerde yapmış yayınları. Yani bitakım üniversitelerin kendi dergilerinde çok rahat yapılan yayınlar ve full bunlarla doluyken onlar yapacă̆ıma ben bir tane yapayım, düzgün yapayım; o da o zaman sayıca az görünüyor. Ya benim için önemli olan yaptığım işin iyi olması. Yeni yeni şey fark ediyorum böyle düşünen çok az insandan biriyim. Bir sürü kişi hatta bana diyorlar ya boşver gönder bi yere gitsin, basılacak bir yere gönder gitsin. Ama o gönderdiğim yer basacak biliyorum hiçbir review almadan edit [düzeltme] almadan basılıcak biliyorum... Ben daha oraya gelemedim, o kadar düşüremedim kendi standartlarımı... O zaman tabi daha uzun sürüyor işte daha sayıca azalıyor. Bi makaleyi üç senedir yayınlatmaya çalışıyorum. Bi tanesi dört senenin sonunda yeni yayınland, bekleme süreleri var hep... Dolayısıyla süre çok uzuyor tabi öbür yerler daha hızlı bi kaç ayda basıliveriyor".
}

Katılımcı bir zanaatkar konumu olarak ele alınabilecek bir bakış açısından, içsel standartları olduğunu ve bu standartların dişsal sayısal standartlarla uyumlu olmadığını belirtmiş, içinde bulunduğu durumu tanımladıktan sonra, üniversitede çalışmayı bırakacağını dile getirmiştir.

SEFAD, 2019; (42): 291-322 
Öğretim üyelerinin, akademik emek sürecinin zanaat yapısına işaret edecek şekilde, kendi işlerini en iyi şekilde yapma saiki ile hareket etseler de akademide yükselmekte olan 'hızlı yayın' anlayışına, sözleşme yenileme, doçentlik, profesörlük unvanlarını alma yönünde genel anlamda uyum sağladı̆̆ı görülmektedir. Katılımcı 28 (Doç. Dr. Erkek, D) daimi kadronun koşulu olan doçentlik unvanının değişen kriterleri temelinde, doçentlik başvurusunu, tam olarak kendini hazır hissetmediği bir tarihe aldığını anlatmaktadır:

"Açık konuşmak gerekirse ben kendimi hazır hissetmeksizin, sırf yeni kriterlere yakalanmamak adına, başvurumu biraz öne çektim... Neden çünkü u benim akademik kriter yani [eski] doçentlik yönetmeliği gereği sağlanması gereken puanları sağlıyorum, hatta çok aşıyorum ama kendimce biraz dedim ya otokontrol, etik e ee, akademik adabı muaşeret ya da teamüller açısından, biraz daha çalışmam gerektiği, birkaç farklı yayın yapmam gerektiği gibi bi düşünceye sahiptim... Başvurmasaydım eğer ee belki iki yıl falan atabilirdi".

Katılımcı 3 (Prof. Dr. Kadın, D) ise performans sistemi temelinde sayısallaştırmanın olumsuz sonuçlarını araçsallaştıran yeni mecraların ortaya çıktığından söz etmektedir:

“Çabucak kötüye kullanabiliyoruz son yıllarda bunu çok gözlemledim mesela geçen gün bir mail geldi inanamadım. Aynen şöyleydi, çok da utanç vericiydi. Bir sosyal bilimler dergisi kurulmuş, başlık şu şekilde geldi. 'Akademik teşvik almak istiyorsanız, akademik yükseltmelerinizi... Şu kadar para gönderin hemen yayınlayalım makalenizi' gibi... Yani işte uluslararası bir dergi yani Pakistan'da da kurulan dergi uluslararası oluyor. Pakistan'daki bir dergiye parayı veriyorsunuz yayınıız, makalenizi yayınlatabilirsiniz. Işte sempozyumlar uluslararası deniliyor içinde bir tane yabancı olmuyor".

Katılımcının ifadesinde yer aldığı üzere, akademik emek sürecinde bir kontrol stratejisi olarak ortaya çıkan güncel bir uygulamanın Akademik Teşvik olduğu görülmektedir. 2014 yılında yürürlüğe giren uygulamada asgari 30 puanın sağlanması durumunda akademisyenlerin ek bir ödeme alması öngörülmüştür (“Yükseköğretim Personel Kanununda", 2014). Birçok katılımcı, çevrelerinde akademik teşvik almaya yönelik yoğun bir çabanın söz konusu olduğu belirtmiştir. Katılımcı 23 (Yrd. Doç. Dr. D.), akademik teşvike yönelik çaba için şöyle demektedir: "Tabi insanlar artık onu şey yapıyor onu artık hesaplayıp ee ona göre işte yayınlarm vesaire ayarlayıp mümkün olduğu kadar ee bundan faydalanmaya çalışıyorlar tabi". Katılımcı 22 (Doç. Dr. D.), akademik teşvike yönelik kolektif bir çabanın, çeşitli üniversitelerde sahteciliğe dair eğilimlerin ortaya çıktığını belirtmektedir. Katılımc 1 (Yrd. Doç. Dr. D.) de aynı duruma işaret etmekte ve şöyle demektedir: “...hani şöyle diyeyim, tabiri caiz ise bu işe uyananlar, 2016'da atıf aramaya başladılar".

Akademik teşvikin yıllık bazda yapılan yayınlar üzerinden verilmesi de stratejik yayın yapma eğilimine katkıda bulunmaktadır. Katılımcı 27 (Yrd. Doç. Dr. D.) bu konuda şöyle demektedir: "Tabi ben kendim için de düşünüyorum. İşte bişeyi basacakken işte geçen tam aralık ayında basılmış. Tüh dedim keşke ocakta basılsaydı... Tabi ama belki o durumda araman lazım derginin editörünü. Ya beni aralık sayısına almayın bi sonrasına alın". Katılımcı böylesi bir düşünme şeklinden rahatsız olduğunu da sözlerine eklemektedir.

Katılımcı 26 (Yrd. Doç. Dr. Erkek, V), performans ölçümlerinin genel anlamda olumsuz sonuçlarına odaklanmakta ve şöyle demektedir: 
“Ama bu performansı ölçemezler, bu ölçülebilecek bir şey değil. Bu yanlış bir şey yani... Ee çünkü neye göre; dediğim gibi makale yaymlatmanın bu kadar ucuz olduğu, para vererek makale yayınlattığın, çalıp çırparak... Veyahut da çeşitli makalelerden ee özetler çıkartıp, alt alta o özetleri sıralayıp, dipnotların kaynakçasını verip bir hakemli dergiye gönderdiğinde yayınlanıyor. Hiçbir... yaratıcılık yok. Ee hiç bi katkı yok, literatüre katkı yok ama yayınlanıyor. Şimdi bu kadar ucuz olduğu bi yerde eğer ki performansa dayalı olursa, herkes makine gibi makale yazıcak ve yayınlancak. Ama bilimsel üretimde, hiç bişey olmucak. Evet makaleler yayınlancak bir sürü dergiler çıkıcak ama onların hiç bi anlamı olmucak".

Kapitalist sistemde, emek gücünün emeğe dönüşümü yolunda, çalışanın maksimum potansiyelini elde etmeye yönelik bir strateji olarak ortaya çıkmış Taylorizm günümüzde, akademik emek sürecinde de uygulanır hale gelmektedir. Taylorizmde işin standartlaştırılması, ölçümlenmesi, kontrol edilmesi ve yoğunlaştırılması öne çıkmaktadır. Özellikle vakıf üniversitelerinde çalışma deneyimine odaklanan bu çalışma temelinde en az kişi ile en fazla çıktının elde edilmesine yönelik akademik Taylorizmin etkileri, yoğun ders yükleri, yüksek öğrenci sayıları, idari işler, tanıtım faaliyetleri temelinde görünür olmaktadır.

Akademik işin birçok farklı faaliyet temelinde yoğunlaştırılmış olmasının yanında, akademik Taylorizmin ortaya çıkardığı akademik işin ölçülebilirliği olgusu akademik yayın sürecinde önemli etkilere sahiptir. Ölçümlenebilirlik temelinde, yayın sürecinde nicelik öne çıarken akademisyenler, işlerini kaybetmemek, kariyerlerinde ilerlemek ve akademik teşvik gibi maddi ödüllere sahip olabilmek adına hızlı yayın yapmanın önemine değinmektedirler. Bu durum da katılımcılar tarafından, akademik üretim alanında sahtecilik, kopyacılık, tekrarcılık ve yüzeysellik gibi olumsuz etkileri çerçevesinde ele alınmıştır.

\section{SONUÇ}

Çalışma, akademide Taylorizmin yükselişi temelinde performans odaklı dönüşümün akademik emek üzerindeki etkisini ele almıştır. Emek gücü, bir çalışanın yaratma, üretme potansiyeli ile ilişkilidir ve bu potansiyel belirsiz bir nitelikteliktedir. Bu berlirsizliği kontrol altına almak ve çalışanın ortaya koyabileceği maksimum potansiyeli elde etmek amaçlı temel bir yönetsel strateji olan Taylorizmin, yükseköğretimde yaşanan dönüşüm ile birlikte, akademik emek sürecine de uygulanır hale geldiği görülmektedir. Bu çerçevede akademik faaliyetlerin standartlaştırılması, ölçümlenebilir hale getirilmesi, iş güvencesinin azaltılması ve böylelikle bireysel performansın kontrol edilebilir hale getirilmesi söz konusudur. Akademik performans yönetiminin yoğunlaştığı akademik faaliyetlerden biri yayın sürecidir.

Temel bir akademik faaliyet olan yayın yapma faaliyeti, günümüzde birçok araç yoluyla ölçümlenmektedir. Bu çalışmada, yayın performansını ölçmek üzere kullanılan, etki faktörü, atıf sayısı ölçümü gibi yöntemler, karmaşık insan faaliyetlerine, sayısal bir karşıllk bulma çabası çerçevesinde ele alınmış, bu yöntemlerin içinde barındırdığı sorunlara değinilmiş ve bu yöntemler üzerine kurulu akademik üretimin sonuçları olarak, çoğunluğu yazar ve hakemler dışında kimse tarafından okunmayan yayınlardan oluşan bir akademik alanın ortaya çımakta olduğuna değinilmiştir. Böylesi bir akademik ortamda, akademisyenlerin atıf alabilecekleri popüler alanlara yöneldikleri ve böylelikle ben de (me 
too) biliminin yaygınlaştığı, akademik üretimde yüzeyselliğe ve sahteciliğe yönelik eğilimlerin baş gösterdiği belirtilmiştir.

Türkiye'de yükseköğretim alanında bilimsel yönetim anlayışının, Taylorizmin yükselişi, kariyerin başlangıcında iş güvencesinin ortadan kalkması, güvenceli bir kadronun koşulu olan doçentlik unvanına yönelik kriterlerin güncellenmesi, norm kadro uygulaması ve doktoralı araştırma görevlilerinin ek ücret almadan 12 saate kadar ders verebilmesi temelinde ele alınmıştır. Türkiye'de akademik Taylorizasyonun olumsuz sonuçları olarak 'atıf çetesi', ücretli yayın yapma gibi eğilimlere ve bu eğilimlerin farkındalığı üzerine YÖK başkanının, yağmacı (predator) dergilerde yapılan yayınların doçentlik başvurularında değerlendirilmeyeceği yönündeki açıklamasına değinilmiştir. Çalışmada tüm bu ele alınan noktalar üzerinden, 2017 yılında gerçekleştirilmiş doktora çalışması çerçevesinde İstanbul ve İzmir illerinde çalışan öğretim üyeleri ile gerçekleştirilmiş yarı yapılandırılmış derinlemesine görüşmeler sonucu elde edilmiş niteliksel veriler analiz edilmiştir.

Çalışma kapsamında, katılımcılardan özellikle kariyerlerinin başında olan Yardımcı Doçent unvanlı öğretim üyelerinin 'hızlı' bir şekilde yayın yapmaya yöneldikleri görülmektedir. Farklı ifadelerde görüldüğü üzere böylesi bir yayın 'stratejisi', akademik merakın, gerçekten sorulmak istenen soruların ikincilleştirilmesini getirebilmektedir. Belirsiz bir nitelik taşıyan, bir zanaat yapısı ve bilgisi üzerine kurulmuş olan akademik işin değerlendirilmesinde kullanılan ölçümleme yöntemlerinin, belirli bir akademik düşünme şeklinde etkili oldukları görülmektedir. Özellikle birçok katılımcının dile getirdiği şekliyle sosyal bilimler alanında araştırma ve buna bağlı olarak yayın sürelerinin uzunluğu; her yıl sözleşmesi yenilenen ya da daha yüksek statü ve ücret/maaş, ayrıca iş güvencesinin artışı, anlamına gelecek daimi kadroya geçme isteğinde olan kişiler açısından 'stratejik' düşünmeyi ve böylelikle hızlı yayın yapma çabasını getirebilmektedir.

'Stratejik' düşünme şekline tam anlamıyla direnen Katılımcı bile içinde bulunduğu konumun onu mesleğini bırakmaya ittiğini dile getirmiştir. Öğretim üyeleri, stratejik okumaları, hızlı yayın yapılacak konuları tercih edebilmekte, kriterlerin çeşitliliğine yönelik yayın yapabilmekte, bu temelde 'oyunu' kurallarına göre oynadıklarını ifade etmekte, bu durum 'bonus' toplamaya benzetilmektedir. Katılımcılar tarafından kariyerinin başında olan kişilerin kapsamlı teorik konularda kitaplar yazabilmekte olduğu, üniversitelere bağlı dergilerde üniversite mensuplarının kolaylıkla yayın yapabildiği, bir araştırmadan tekrar tekrar yayın yapılabildiği, herhangi bir hakem geri bildirimi olmaksızın, ücret karşılığı makalelerin yayınlanabildiği ve kopyalama yapıştırma usulüyle bir araya getirilmiş makaleleri yayınlayacak mecraların ortaya çıktığı dile getirilmektedir. Bu durum akademik üretimde yaratıcılı̆̆ın geri plana itilmesi, niceliğin niteliğin önüne geçmesi ve en önemlisi akademik çalışmanın, bilim yapmanın kendisinin ikincilleştirilmesi olarak ele alınabilir.

Zanaat bilgisi üzerine kurulmuş olan akademik emek sürecinde akademisyenin kendi emek sürecindeki kontrolü kaybettiği, ölçümlenebilirlik anlayışı üzerine kurulu bir performans denetiminin yükseldiği görülmektedir. Fakat akademik üretimin zanaat yapısı, ölçümlemenin zorluğunu, özellikle üretimde aranan niteliği belirlemenin güçlüğünü beraberinde getirmekte; ölçümlemenin, nitelik karşısında niceliğin önemini arttırdığı, bu temelde de sahteciliğe kadar varabilecek olumsuz uygulamalar üzerine kurulu bir niceliksel artışın söz konusu olduğu görülmektedir. 
Çeşitli olumsuz yayın yapma stratejilerinin ortaya çıkması, çalışmada görüldüğü üzere, akademide performans denetiminin, ders verme ve idari işler gibi diğer faaliyetlerden bağımsız şekilde ele alınması ile ilintilidir. Günümüzde neoliberal politikalar temelinde şekillenen yükseköğretim alanında, bilimsel yönetim ilkelerinin doğru bir şekilde oluşturulmasında, akademisyenlerin içinde bulundukları kurumun kaynaklarının ve yerine getirdikleri diğer akademik faaliyetlerin göz önünde bulundurulması önemlidir. Şüphesiz, diğer meslekler gibi akademisyenlik mesleği ve bu temelde akademik emek süreci de bir tür kontrole tabi olacaktır. Bu kontrolü gerçekleştirirken, içinde bulunulan ülkenin ve yükseköğretim sisteminin kendine özgü özelliklerinin göz önünde bulundurulması, niteliksel gelişmenin niceliksel büyümeye eşlik etmesini sağlayabilecektir. Bu çalışma, akademik Taylorizasyonun olumsuz etkilerine dikkat çekmek ve hedeflenen dönüşümün, uygulamada getirdiği sonuçları anlamlandırmak üzere akademik üretimde niceliğin artan önemi üzerinde durmuştur.

\section{SUMMARY}

Building on Braverman's (2008) 'Labor Process Theory', this study focuses on the rise of academic Taylorism and the performance-based transformation of the academic labor process. In the capitalist system, the employer purchases labor power, that is the potential of a worker to produce. This potential is the basis of the labor contract between the employer and the employee. The worker carries a potential to produce and a will to realize this potential. The employer's interest is to capture the maximum potential of the worker. There are many control strategies such as Taylorism and recently Neo-Taylorism, implemented by the management to ensure that the worker puts forth her maximum potential.

Labor process theory proposes that labor power can be controlled with the use of scientific management strategies to ensure that craft knowledge inherent in any type of labor process is carefully studied and this knowledge is transferred to the management. With the use of this knowledge, the design and implementation of work is separated, work is standardized, and worker performance is carefully assessed. Taylorism leads to the deskilling of the worker making workers replaceable and making work insecure. In case of academic work, work is standardized, there is constant performance assessment, academic labor power becomes replaceable and academic work becomes insecure.

Academics are defined as professional workers and academic work itself is built on craftsmanship. The implementation of Taylorism in higher education in the neoliberal era has changed the organization of academic work significantly throughout the world and in Turkey. Part-time work, limited contracts and constant performance assessment have come to define academic work that is becoming increasingly insecure. Academic Taylorism in Turkey becomes evident in developments such as the loss of job security in the early years of academic career (for research assistants), the updated performance criteria for associate professorship, which may be considered as a tenured position, and the recent regulation that allows research assistants holding a $\mathrm{PhD}$ to teach classes for up to 12 weekly hours without extra pay. The basic assumption of the paper, which is the fact that academic Taylorism leads to superficiality in academic endeavors come into picture in newspaper articles which proclaim the establishment of 'citation organizations' in Turkey and the head of Higher Education Council (YÖK)'s announcement that publications in 'predator journals' will not be taken into consideration in applications for associate professorship.

SEFAD, 2019; (42): 291-322 
In order to understand the results of the restructuring of academic work, semi structured in-depth interviews have been conducted with 28 teaching members working in social sciences departments of 17 different institutions located in the cities of Istanbul and Izmir. 20 in-depth interviews have been conducted in Istanbul and 8 interviews in Izmir. Labor Process Theory has been the framework in the preparation of interview themes and questions. This is a qualitative study designed to assess the real, everyday experiences of academics in Turkey. To ensure a more homogenous and comparable sample group, academics working in social sciences were targeted. In the neoliberal era where everything is evaluated based on immediate economic benefit, social sciences becomes problematic. Social sciences were also chosen on the grounds that they do not yield immediate results and economic benefit. The study was built on the experience of academics working in geography, sociology, psychology, philosophy, history and art history departments.

This research has shown that participants, especially Assistant Professors, the ones who are in the early years of their career are looking for 'fast' ways to publish. Participants state that they do not have the time to conduct thorough research and must choose quantity over quality in their research endeavors. A 'strategic' way of thinking is being developed where the academic curiosity and the real questions behind academic endeavors are being side-tracked. It is seen that the methods used in evaluation of academic work which is ambiguous in nature and built on craftsmanship knowledge, are constitutive in this new academic thinking. The teaching members may carry out strategic literature reviews, choose to publish in areas that do not require vigorous study and try to publish in accordance with performance criteria. A participant regards this as 'playing by the rules' while another participant likens this to collecting 'bonuses'. The participants also acknowledge some newly emerged mediums that require a certain fee and allow academics to quickly publish their papers without any reviews.

Accordingly, in academic work, creativity loses its significance, quantity gains importance at the expanse of quality and the scientific enquiry becomes a means rather than an end. This paper proposes that performance criteria should be established in consideration of other academic activities the academics have to perform and the specific nature of Turkey's higher education. This study has focused on the negative consequences of academic Taylorism in Turkey and how the targeted transformation of academic work has resulted in the increasing importance of quantity in academic production. 


\section{KAYNAKÇA}

2547 Sayılı Yükseköğretim Kanunu (tarih yok).Yükseöğretim Kurulu. Erişim adresi: http://www.mevzuat.gov.tr/MevzuatMetin/1.5.2547.pdf

Ak, M. Z. ve Gülmez, A. (2006). Türkiye'nin Uluslararası Yayın Performansının Analizi. Akademik Incelemeler Dergisi, 1(1), 22-49.

Al, U. ve Soydal, İ. (2012). Dergi Kendine Atıfının Etkisi: Energy Education Science and Technology Örneği. Türk Kütüphaneciliği, 26(4), 699-714.

Altbach, P. G. (1997). An International Academic Crisis? The American Professoriate in Comparative Perspective. Daedalus, 126(4), 315-338.

Altbach, P. G. (1999). Survival of the Fittest: The University of Buenos Aires Model. International Higher Education(14), 8-9.

Altbach, P. G. (2001). The American Academic Model in Comparative Perspective. P. G. Altbach, P. J. Gumport, ve D. B. Johnstone (Dü) içinde, In Defense of American Higher Education (s. 11-37). Baltimore: The Johns Hopkins University Press.

American Association for University Professors. $(2017,03)$. Research. Trends in the Academic Labor Force, 1975-2015 Erişim adresi: https://www.aaup.org/sites/default/files/Academic\%20Labor\%20Force\%20Trends\%2019 75-2015.pdf

Atalay, S. (2017a). Neoliberal Policies And Higher Education: A Comparison Between Sociology And Psychology Departments With Regard To Public And Private Universities In Turkey. Sosyoloji Dergisi(35), 45-59.

Atalay, S. (2017b). Yükseköğretim Stratejileri ve Akademisyenlik Mesleğinin Değiş̧imi: Sosyal Bilimler Örneği. İzmir: Ege Üniversitesi Sosyal Bilimler Enstitüsü Yayınlanmamış Doktora Tezi.

'Atıf çetesi' rektörlük yolunda. (2015, 03, 18). Memurlar.net. Erişim adresi: https://www.memurlar.net/haber/505907/atif-cetesi-rektorluk-yolunda.html

Balaban, U. (2012). Türkiye'de Yükseköğretim Reformu ve ABD'de Endüstri- Üniversite İlişkisinin Tarihi. Ankara Üniversitesi SBF Dergisi, 67(4), 25-61.

Bingöl, B. (2012). Üniversite Özerkliğinin Değişen Tanımı ve Üniversitelerin Yeniden Yapılandırılması. Hacettepe Hukuk Fakültesi Dergisi, 2(2), 39-75.

Biswas, A. K. ve Kirchherr, J. (2015, 04 11). Prof, no one is reading you. The Straits Times. Erişim adresi: https://www.straitstimes.com/opinion/prof-no-one-is-reading-you

Bok, D. (2007). Piyasa Ortamında Üniversiteler. (B. Yıldırım, Çev.) İstanbul: Bilgi Üniversitesi Yayınları.

Brancaleone, D. ve O'Brien, S. (2011). Educational Commodification and The (Economic) Sign Value of Leraning Outcomes. British Journal of Sociology of Education, 32(4), 501-519.

Braverman, H. (2008). Emek ve Tekelci Sermaye. (Ç. Çidaml, Çev.) İstanbul: Kalkedon.

Clarke, S. (2014). Neoliberal Toplum Kuramı. A. Saad-Filho, ve D. Johnston (Dü) içinde, Neoliberalizm Muhalif Bir Seçki (Ş. Başlı, ve T. Öncel, Çev., s. 91-105). İstanbul: Yordam Kitap.

Coşar, S. ve Ergün, H. (2015). Free-Marketization of Academia through Authoritarianism: The Bologna Process in Turkey. Alternate Routes, 101-124. 
Coşkun, A. ve Ünal, G. (2013). Higher Education in Turkey: Trends Towards Self-Steering Public Universities. Yükseköğretim Dergisi, 1, s. 40-47.

Crouch, C. (2014). Neoliberalizmin Garip Ölümsüzlüğü. (U. Gezen, Çev.) İstanbul: Açllım Kitap.

Crowley, M., Tope, D., Joyce, C. L. ve Hodson, R. (2010). Neo-Taylorism at Work: Occupational Change in the Post-Fordist Era. Social Problems, 57(3), 421-447.

Curry, S. (2012, 08 13). Sick of Impact Factors. Erişim adresi: http://occamstypewriter.org/scurry/2012/08/13/sick-of-impact-factors/

Curry, S. (2019, 01 31). Thinking globally about research evaluation - LIS-Bibliometrics talk. Erişim adresi: http://occamstypewriter.org/scurry/2019/01/31/thinking-globally-researchevaluation/

Curtis, J. W. (2014, 04). Research. Erişim adresi: https://www.aaup.org/sites/default/files/Academic\%20Labor\%20Force\%20Trends\%2019 75-2015.pdf

Çavdar, T. (2013). Neoliberalizmin Türkiye Seyir Defteri. İstanbul: Yazılama Yayınevi.

Çelik, Z. (2012). Bologna Süreci'nin Avrupa Yükseköğretim Sistemi Üzerine Etkileri. Yükseköğretim ve Bilim Dergisi, 2(2), 100-105.

Çetinsaya, G. (2014). Büyüme, Kalite, Uluslararasılaşma: Türkiye Yükseköğretimi İçin Bir Yol Haritası. Eskişehir: Anadolu Üniversitesi Basımevi .

De Angelis, M. ve Harvie, D. (2009). Cognitive Capitalism' and the Rat-Race: How Capital Measures Immaterial Labour in British Universities. Historical Materialism, 17, 3-30.

Demir, E., Cennet, G. D. ve Özdemir, M. Ç. (2017). Akademik Yükseltme ve Atama Sürecine Yönelik Öğretim Üyesi Görüşleri. Yükseköğretim ve Bilim Dergisi, 7(1), 12-23.

Devlet Yükseköğretim Kurumlarında Öğretim Elemanı Norm Kadrolarının Belirlenmesine ve Kullanılmasına İlişkin Yönetmelik (2018, 11 2). Resmigazete (Sayı:30583). Erişim adresi: http://www.resmigazete.gov.tr/eskiler/2018/11/20181102-14.htm.

Dinçer, Ö. ve Yılmaz, C. (2003). Kamu Yönetiminde Yeniden Yapılanma: 1. Ankara: T.C. Başbakanlık.

Doçentlik Başvuru Şartları -2018 Ekim Dönemi. (tarih yok). Üniversitelerarası Kurul. Erişim adresi: http://www.uak.gov.tr/?q=node/86\#2018E

Dominelli, L. ve Hoogvelt, A. (1996). Globalization, Contract Government and the Taylorization of Intellectual Labour in Academia. Studies in Political Economy, 49, 71-100.

Donald, A. (2013, 03, 14). It's Time To Resist The Pressure. Erişim adresi: http://occamstypewriter.org/athenedonald/2013/03/14/its-time-to-resist-the-pressure/

Durmaz, N. (2017). Akademinin Prekaryası: 50d'li Araştırma Görevlileri. Ankara Üniversitesi SBF Dergisi, 72(4), 945-975.

Emery, C. R., Kramer, T. R. ve Tian, R. G. (2003). Return to academic standards: a critique of student evaluations of teaching effectiveness. Quality Assurance in Education, 11(1), 3746.

Enders, J., De Boer, H. ve Weyer, E. (2013). Regulatory Autonomy and performance: the reform of higher education re-visited. Higher Education, 65, 5-23. 
Erguvan, D. (2013). Vakıf Üniversitelerinin Türkiye Yükseköğretim Sistemi Üzerindeki Etkilerine Dönük Akademisyen Algıları. Kuram ve Uygulamada Eğitim Bilimleri, 13(1), 137-160.

Evans, G. R. (2007). Akademisyenler ve Gerçek Dünya. İstanbul: İstanbul Bilgi Üniversitesi Yayınları.

Gendron, Y. (2008). Constituting the Academic Performer: The Spectre of Superficiality and Stagnation in Academia. European Accounting Review, 17(1), 97-127.

Glesne, C. (2015). Nitel Araştırmaya Giriş. (A. Ersoy, Y. Pelin, Dü. ve P. Yalçınoğlu, Çev.) Ankara: Anı Yayıncilık.

Gruber, T. (2014). Academic Sell-Out: How An Obsession With Metrics And Rankings Is Damaging Academia. Journal of Marketing for Higher Education, 24(2), 165-177.

Herdman, E. A. (2012). Liderlik ve Yönetim: Teori Var Pratik Yok? (Ö. Yazıcı-Korkmaz, Dü.) Hemşirelikte Eğitim ve Araştırma Dergisi, 12(1), 3-9.

Hız, G. (2010). 1980 Sonrasında Türkiye'de Yükseköğretimde Piyasalaştırma ve Özelleştirmedeki Gelişmeler. Muğla Üniversitesi Sosyal Bilimler Enstitüsü Dergisi(25), 5580.

Itoh, A. (2002). Higher Education Reform in Perspective: The Japanese Experience. Higher Education, 43(1), 7-25.

Kahveci, E. ve Nichols, T. (2006). The Other Car Workers: Work, Organisation and Technology In The Maritime Car Carrier Industry. Houndmills, Basingstoke, Hampshire: Palgrave Macmillan.

Kaplan, P. (2017, 07 28). Akademisyenlerin 'atıf' çetesi. Habertürk. Erişim adresi: https://www.haberturk.com/yazarlar/pervin-kaplan/974474-akademisyenlerin-atifcetesi\#

Kılıç, M. (2013). Akademinin Sosyolojisine Dair Bir Derkenar: Akademia'nın SosyoPsikolojik Dinamikleri. Yükseköğretim Dergisi, 3(1), 30-39.

Kogan, M. ve Teichler, U. (2007). Key Challanges to the Academic Profession and Its Interface with Management: Some Introductory Thoughts. M. Kogan, ve U. Teichler (Dü) içinde, Key Challanges to the Academic Profession (s. 9-15). Paris and Kassel: UNESCO Forum on Higher Education.

Köse, A. H. ve Öncü, A. (2000). İşgücü Piyasaları Ve Uluslararası İş Bölümünde Uzmanlaşanın Mekansal Boyutları: 1980 Sonrası Dönemde Türkiye İmalat Sanayi. Toplum ve Bilim(86), 72-90.

Kramer, J. (2008, 01 13). Taylorized Academic Labor. History News Network. Erişim adresi: http://historynewsnetwork.org/article/44931

Lattier, D. (2016, 10 26). Why Professors Are Writing Crap That Nobody Reads? Intelectural Takeout. Erişim adresi: https://www.intellectualtakeout.org/blog/why-professors-arewriting-crap-nobody-reads

Lynch, K. (2014, 08, 18). Control By Numbers: New Managerialism and Ranking In Higher Education. Ctitical Studies in Higher Education, 1-18.

Marx, K. (1999). Ücretli Emek ve Sermaye Ücret Fiyat ve Kar. (İ. Yarkın, ve İ. M.A., Çev.) İnter Yayınları.

Marx, K. (2013). Kapital 1. Cilt. İstanbul: Yordam Kitap. 
Marx, K. (2014). Grundrisse. İstanbul: Birikim Yayınları.

Miller, H. (1996). Academics and Their Labour Process. C. Smith, D. Knights, ve H. Willmott (Dü) içinde, White- Collar Work The Non-Manual Labour Process (s. 109-137). London: Macmillan Press.

Mills, C. W. (1969). White Collar The American Middle Classes. London\&Oxford\&New York: Oxford University Press.

Mills, C. W. (2000). The Sociological Imagination. Oxford \& New Yord: Oxford University Press.

Mollis, M. (2001). The Americanization of Higher Education Reforms in Argentina. World Studies in Education, 2(2), 29-46.

Musselin, C. (2013). Redefinition of the Relationship Between Academics and Their University. Higher Education(65), 25-37.

Mutioğlu, H. (2016). Homo Economicus Ve Emeğin Değeri Bağlamında Anlamını Arayan Homo Academicus. Atatürk Üniversitesi İktisadi ve İdari Bilimler Dergisi, 30(5), 1003-1017.

Nalçaoğlu, H. (1999). Türkiye'nin Yeni Üniversite Düzeni: Kriz ve Kalite. Doğu Batl, Akademi ve İktidar(7), 91-106.

Nichols, T. (1980). The Capitalist Labour Process. T. Nichols (Dü.) içinde, Capital and Labour (s. 21-41). London: The Atholone Press.

Organisation for Economic Cooperation and Development Türkiye. (2017). Education At A Glance. Erişim adresi: http://www.oecd.org/education/skills-beyondschool/EAG2017CN-Turkey-Turkish.pdf

Orer, H. S. (2011). Türkiye'nin Bilimsel Yayın Performansı. ANKEM Dergi, 25, 134-138.

Öğrenci Sayıları Özet Tablosu (tarih yok). Yükseköğretim Bilgi Yönetim Sistemi,. Erişim adresi: https://istatistik.yok.gov.tr/

Öğretim Elemanları Sayısı Özet Tablosu (tarih yok). Yükseköğretim Kurulu. 2017-2018 Öğretim Yılı Yükseköğretim İstatistikleri. Erişim adresi: https://istatistik.yok.gov.tr/

Özcan, D. ve Çakır, H. (2016). Üniversite- Toplum, Devlet, Piyasa/ Sermaye İlişkileri Bağlamında Üniversite Özerkliği. Yükseköğretim ve Bilim Dergisi, 6(1), 31-40.

Parker, M. ve Jary, D. (1995). The McUniversity: Organization, Management and Academic Subjectivity. Organization, 2(2), 319-338.

Pedro, F. (2009). Continuity and Change in the Academic Profession in European Countries. Higher Education in Europe, 34(3-4), 411-429.

Rajagopal, I. ve Farr, W. D. (1992). Hidden Academics: The Part Time Faculty in Canada. Higher Education, 24, 317-331.

Reid, A. (2003). Understanding Teacher's Work: Is There Still a Place for Labour Process Theory? British Journal of Sociology of Education, 24(5), 559-573.

Rhoades, G. (2007). The Study of Academic Profession. P. J. Gumport (Dü.) içinde, Sociology of Higher Education: Contributions and Their Contexts (s. 113-146). Maryland: John Hopkins University Press.

Roberts, K. A. ve Donahue, K. A. (2000). Professing Professionalism: Bureaucratization and Deprofessionalization In The Academy. Sociological Focus, 33(4), 365-383. 
Seglen, P. O. (1992). The Skewness of Science. Journal of the American Society for Information Science, 43(9), 628-638.

Seglen, P. O. (1997). Why the impact factor of journals should not be used for evaluating research. $B M J, 314,498-513$.

Simkin, M. V. ve Roychowdhury, V. P. (2003). Read Before You Cite! Complex Systems, 14, 269-274.

Symth, J. (1995). Introduction. Academic Work (s. 1-16). içinde Buckingham: SRHE \& Open University Press.

Tancred Sheriff, P. (1985). Craft, Hierarchy and Bureaucracy: Modes of Control of the Academic Labour Process. Canadian Journal of Sociology, 10(4), 369-390.

Tarihçe (tarih yok). Yükseköğretim Kurulu. Erişim adresi: http://www.yok.gov.tr/web/guest/tarihce

Taylor, F. W. (1997). Bilimsel Yönetimin Ilkeleri. (B. H. Akın, Çev.) Konya: Çizgi Kitabevi Yayınları.

Teichler, U., Arimoto, A. ve Cummings, W. K. (2013). The Changing Academic Profession: Major Findings Of A Comparative Survey. Dordrect\&Heidelberg\&New York\&London: Springer.

Tekeli, İ. (2003). Dünya'da ve Türkiye'de Üniversite Üzerine Konuşmanın Değişik Yolları. Toplum ve Bilim(97), 123-143.

Thompson, P. (1989). The Nature of Work. Houndmills, Basingstoke, Hampshire \& London: The Macmillan Press.

Tilak, J. B. (2012). Financing Of Higher Education: Traditional Versus Modern Approaches. Yükseköğretim Dergisi, 2(1), 28-37.

Tonta, Y. (2014, 07 03). AkademikÖğretim Üyeliğine Yükseltme ve Yayın Destekleme Ölçütleriyle İlgili Bir Değerlendirme. Erişim adresi: http://yunus.hacettepe.edu.tr/ tonta/yayinlar/tonta-yukseltme-kriterleri-hakkindadegerlendirme-11-Temmuz-2014.pdf

Tuncer, M., Dikmen, M., Tanaş, R., Bahadır, F., Temur, M. ve Uluğ, H. (2018). Doçentlik Süreci ve Bazı Akademik Kadrolardaki Düzenlemelere Yönelik Öğretim Elemanlarının Görüşlerinin Değerlendirilmesi. Turkish Studies, 13(11), 1311-1335.

Türkiye İstatistik Kurumu. (2017, 12 19). Eğitim Harcamaları İstatistikleri 2016. Erişim adresi: www.tuik.gov.tr/PdfGetir.do?id=24679

Türlerine Göre Mevcut Üniversite Sayısı (tarih yok). Yükseköğretim Bilgi Yönetim Sistemi,. Erişim adresi: https://istatistik.yok.gov.tr/

Ulutürk, S. ve Dane, K. (2011). Yükseköğretimin Finansmanı; Neoliberal Dönüşüm ve Türkiye. In F. Ercan ve S. Korkusuz-Kurt (Eds), Metalaşma ve İktidarın Baskınındaki Üniversite (s. 413-438). İstanbul: Sav Yayınc1lk.

University and College Union. (2016). Precarious work in higher education: A snapshot of insecure contracts and institutional attitudes. Erişim adresi: https://www.ucu.org.uk/media/7995/Precarious-work-in-higher-education-a-snapshotof-insecure-contracts-and-institutional-attitudes-Apr16/pdf/ucu_precariouscontract_hereport_apr16.pdf

Ünlütürk Ulutaş, Ç. (2011). Türkiye'de Sağllk Emek Sürecinin Dönüşümü. Ankara: NotaBene Yayınları. 
Van der Sluis, M. E., Reezigt, G. J. ve Borghans, L. (2017). Implementing New Public Management Strategies in Education. Education Policy, 31(3), 303-329.

Vanclay, J. K. (2012). Impact Factor: outdated artefact or stepping-stone to journal certification? Scientometrics, 92(2), 211-238.

Willis, E., Carryer, J., Harvey, C., Pearson, M. ve Henderson, J. (2017). Austerity, new public management and missed nursing care in Australia and New Zealand. Journal of Advanced Nursing, 73(12), 3102-3110.

Wojcicka Sharff, J. ve Lessinger, J. (1994). The Academic Sweatshop: Changes in the Capitalist Infrastructure and the Part-Time Academic. Anthropology Today, 10(5), 12-15.

'Yağmacı' Dergi Yayınları Akademik Yükseltmelerde Kullanılmayacak (2019, 03, 09). Haberler. Erişim adresi: https://www.yok.gov.tr/Sayfalar/Haberler/yagmaci-dergiyayinlarina-onlem.aspx

YÖK'ten, 50/d ve yardımcı doçentliğe geçiş için genelge. (2017, 11, 17). Memurlar.net. Erişim adresi: $\quad$ https://www.memurlar.net/haber/708682/yok-ten-50-d-ve-yardimci-docentlige-gecisicin-genelge.html

Yükseköğretim Personel Kanununda Değişiklik Yapılmasına Dair Kanun, (2014, 11, 14). Resmigazete (Sayl: 29175). Erişim adresi: http://www.resmigazete.gov.tr/eskiler/2014/11/20141114-1.htm

Zeybek, S. O. (2015, 05 30). Akademisyenler Ne İş Yapar? Bir Üniversitenin Sertifikalandırlma Süreci. Erişim adresi: http://yesilgazete.org/blog/2015/05/30/akademisyenler-ne-isyapar-bir-universitenin-sertifikalandirilma-sureci-sezai-ozan-zeybek/ 